\title{
Geologic Map of the Pagosa Springs 7.5' Quadrangle, Archuleta County, Colorado
}

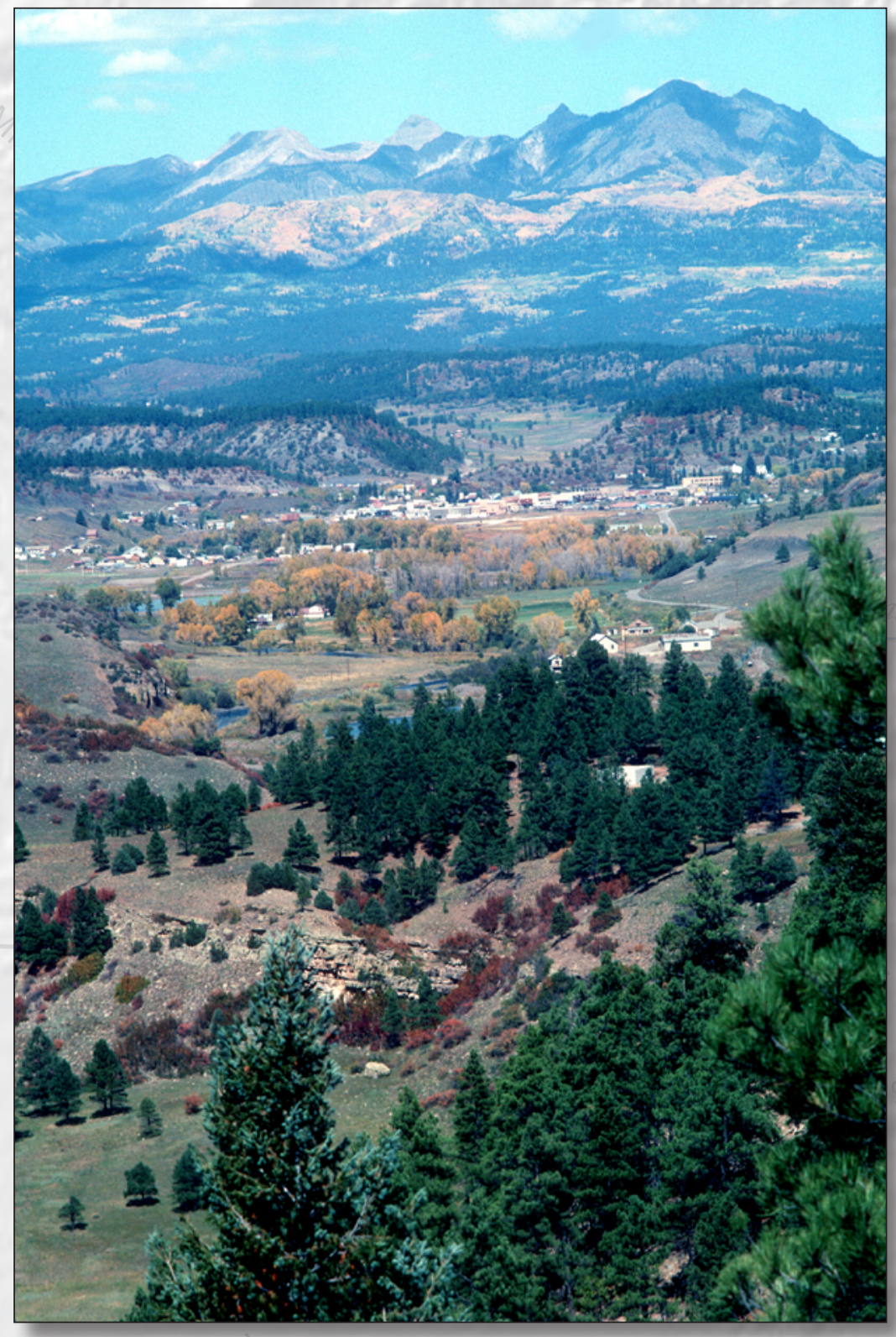

Pamphlet to accompany

Scientific Investigations Map 3419

U.S. Department of the Interior

U.S. Geological Survey 
Cover. Photograph showing town of Pagosa Springs, Colo. The low terraces are north of town, and Pagosa Peak is on skyline. Taken about 2 miles south of Pagosa Springs, just outside of southern map area border, looking north. Photograph by David Moore, 1980. 


\section{Geologic Map of the Pagosa Springs 7.5' Quadrangle, Archuleta County, Colorado}

By David W. Moore and David J. Lidke

Pamphlet to accompany

Scientific Investigations Map 3419 


\section{U.S. Department of the Interior \\ RYAN K. ZINKE, Secretary}

\section{U.S. Geological Survey James F. Reilly II, Director}

\section{U.S. Geological Survey, Reston, Virginia: 2018}

For more information on the USGS - the Federal source for science about the Earth, its natural and living resources, natural hazards, and the environment-visit https://www.usgs.gov or call 1-888-ASK-USGS.

For an overview of USGS information products, including maps, imagery, and publications, visit https://store.usgs.gov.

Any use of trade, firm, or product names is for descriptive purposes only and does not imply endorsement by the U.S. Government.

Although this information product, for the most part, is in the public domain, it also may contain copyrighted materials as noted in the text. Permission to reproduce copyrighted items must be secured from the copyright owner.

Suggested citation:

Moore, D.W., and Lidke, D.J., 2018, Geologic map of the Pagosa Springs 7.5' quadrangle, Archuleta County, Colorado: U.S. Geological Survey Scientific Investigations Map 3419, pamphlet 24 p., scale 1:24,000, https://doi.org/10.3133/sim3419.

The ScienceBase data release GIS files that support this report can be found at https://doi.org/10.5066/P9WRSUI6

ISSN 2329-132X (online) 


\section{Contents}

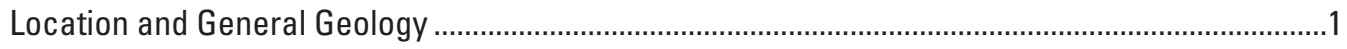

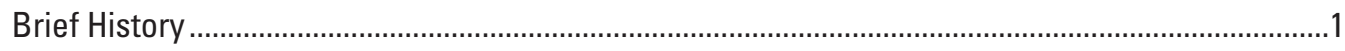

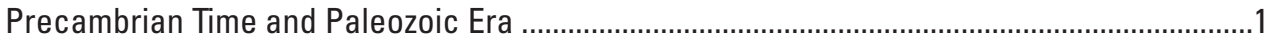

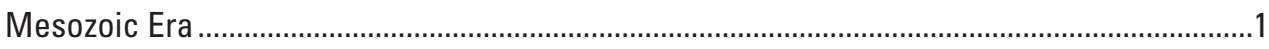

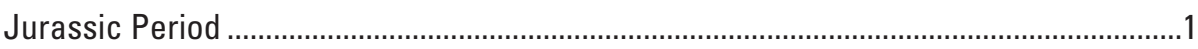

Middle and Late Jurassic Epoch (175-145 Ma) .....................................................

Cretaceous Period ........................................................................................................

Early Cretaceous Epoch (145-100 Ma) ....................................................................

Late Cretaceous Epoch (100-66 Ma) ......................................................................

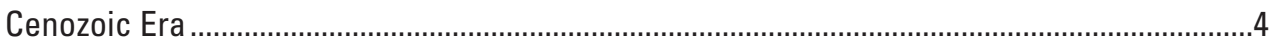

Paleogene Period (66-23 Ma).................................................................................

Paleocene, Eocene, and Oligocene Epochs ..............................................................4

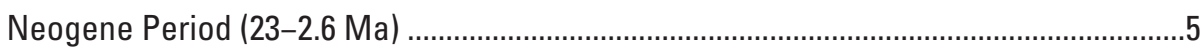

Miocene and Pliocene Epochs............................................................................

Quaternary Period (2.6 Ma-Present) ...........................................................................

Pleistocene and Holocene Epochs .........................................................................5

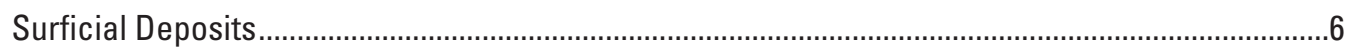

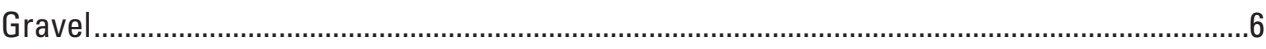

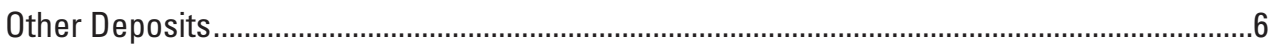



Cross Sections and Subsurface Information .........................................................................

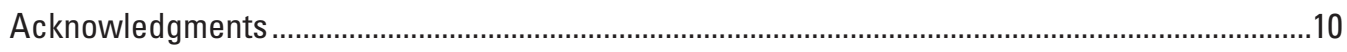

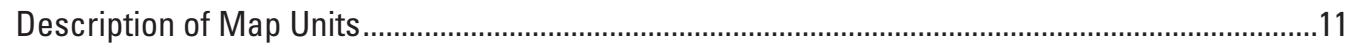

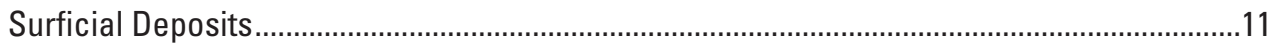

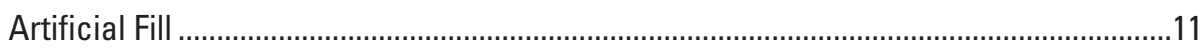

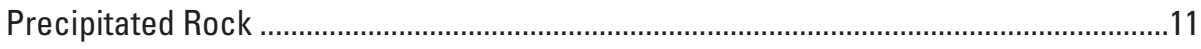

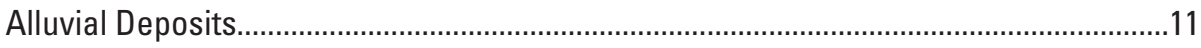

Glacial and Glaciofluvial Deposits ...........................................................................13

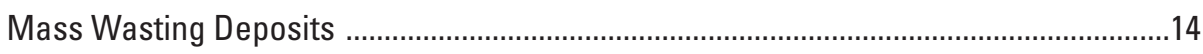

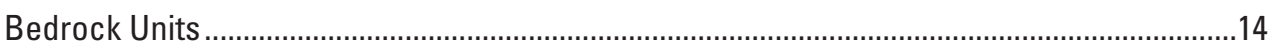

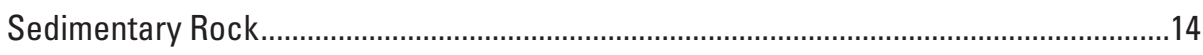

Igneous and Metamorphic Rock ..............................................................................18

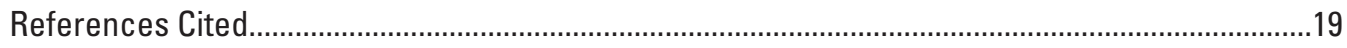

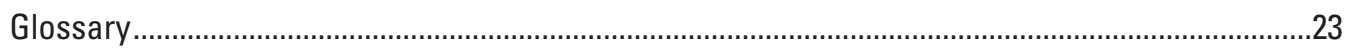

\section{Sheet}

Geologic Map of the Pagosa Springs 7.5' Quadrangle, Archuleta County, Colorado .................. link 


\section{Figures}

1. Location and setting of Pagosa Springs quadrangle showing outline of quadrangle......2

2. Photograph showing town of Pagosa Springs, Colo. The low terraces are north of town, and Pagosa Peak is on skyline

3. Oldest fluvial terrace gravel (Qtg5) in gravel pit, on Oakbrush Hill in the map area, section 6, Township $35 \mathrm{~N}$., Range $2 \mathrm{~W}$; thickness $18 \mathrm{ft}$

\section{7}

4. Pinedale glacial outwash (Qop), 15-25-foot-thick, overlying shale of the Mesaverde Group (Kmv) exposed at Mesa Ditch in the northeast part of the Pagosa Springs 7.5' quadrangle

5. Stratigraphic column showing map units of the Pagosa Springs 7.5' quadrangle ..........9

\section{Conversion Factors}

U.S. Customary Units to International System

\begin{tabular}{|c|c|c|}
\hline Multiply & By & To obtain \\
\hline \multicolumn{3}{|c|}{ Length } \\
\hline inch (in.) & 2.54 & centimeter $(\mathrm{cm})$ \\
\hline inch (in.) & 25.4 & millimeter $(\mathrm{mm})$ \\
\hline foot $(\mathrm{ft})$ & 0.3048 & meter $(\mathrm{m})$ \\
\hline mile (mi) & 1.609 & kilometer $(\mathrm{km})$ \\
\hline
\end{tabular}




\section{Divisions of Geologic Time Used in This Report ${ }^{1}$}

\begin{tabular}{|c|c|c|c|}
\hline Period & & & $\mathrm{Age}^{2}$ \\
\hline \multirow{6}{*}{ Quaternary } & \multirow{3}{*}{ Holocene $^{3}$} & late & $0-4.2 \mathrm{ka}$ \\
\hline & & middle & $4.2-8.2 \mathrm{ka}$ \\
\hline & & early & $8.2-11.7 \mathrm{ka}$ \\
\hline & \multirow{3}{*}{ Pleistocene $^{4}$} & late & $11.7-126 \mathrm{ka}$ \\
\hline & & middle & $126-781 \mathrm{ka}$ \\
\hline & & early $^{5}$ & $781 \mathrm{ka}-2.58 \mathrm{Ma}$ \\
\hline \multirow{6}{*}{ Cretaceous } & \multirow{6}{*}{ Upper $^{6}$} & Maastrichtian & $66.0-72.1 \mathrm{Ma}$ \\
\hline & & Campanian & $72.1-83.6 \mathrm{Ma}$ \\
\hline & & Santonian & $83.6-86.3 \mathrm{Ma}$ \\
\hline & & Coniacian & $86.3-89.8 \mathrm{Ma}$ \\
\hline & & Turonian & 89.8-93.9 Ma \\
\hline & & Cenomanian & $93.9-100.5 \mathrm{Ma}$ \\
\hline
\end{tabular}

${ }^{1}$ Divisions of geologic time were selected for emphasis in this study.

${ }^{2} \mathrm{Ma}$, million years; ka, thousand years.

${ }^{3}$ Subdivisions of the Holocene are informal divisions advocated by Walker, M.J.C and others (2012).

${ }^{4}$ Subdivisions of the Pleistocene are informal divisions from Cohen and others (2013; updated).

${ }^{5}$ Early Pleistocene as applied here is the combination of the Calabrian and Gelasian Ages from Cohen and others (2013; updated).

${ }^{6}$ Subdivisions of the Upper Cretaceous are divisions from Cohen and others (2013; updated). 



\title{
Geologic Map of the Pagosa Springs 7.5' Quadrangle, Archuleta County, Colorado
}

\author{
By David W. Moore and David J. Lidke
}

\section{Location and General Geology}

The Pagosa Springs 7.5' quadrangle is in southwest Colorado between the San Juan Basin to the southwest and the San Juan Mountains north and east; it covers an area of about 59 sq. miles (mi) (fig. 1). The town of Pagosa Springs, population 1,727 (U.S. Census, 2010) is the Archuleta County seat. U.S. Highway 160 runs east-west through the center of town. The San Juan Basin, centered in northwestern New Mexico, is enclosed by outcrops of Late Cretaceous sedimentary rocks. Pagosa Peak (12,640 ft) north of the quadrangle and other nearby peaks of the San Juan Mountains to the east, are composed of volcanic rocks (figs. 1 and 2). The San Juans are thick remnants of nearly level layers of tuff erupted 30-25 million years ago (Ma) from explosive, caldera-forming volcanoes (McIntosh and Chapin, 2004; Lipman, 2006). The tuff covers older volcanic rocks that were deposited on a late Eocene low-relief erosion surface. Later, in the Neogene and Quaternary, streams and glaciers carved the volcanic layers into rugged peaks. Tuff may have once covered the map area (Atwood and Mather, 1932), but the only remaining volcanic rock today is gravel washed in by streams.

The rocks that crop out in the quadrangle are shales and sandstones deposited in an inland sea mainly in Late Cretaceous time about 100 to $70 \mathrm{Ma}$. These rocks are as much as $1,690 \pm 300$ feet (ft) thick. After the inland sea withdrew from the region, an arch (anticlinorium) lifted and tilted the formerly horizontal layers of shale and sandstone and the layers were later faulted. Weathering and erosion of the land accentuated the hard sandstone layers, preserving them as tilted (dipping) ledges evident along U.S. Highway 160. Beneath the surface, pre-Cretaceous Mesozoic rock layers lie unconformably on Precambrian gneiss and granite (depicted in cross sections). In Pagosa Springs, a geothermal test drill hole 1,483 ft deep, penetrated Precambrian rocks at a depth of 1,380 ft (Galloway, 1980). Similarly, a drill hole in the northeast part of the map area and another just outside the western map border also penetrate Mesozoic and Precambrian rock.

\section{Brief History}

\section{Precambrian Time and Paleozoic Era}

Precambrian gneiss and granite formed 1,650-1,450 Ma in this region when volcanic island arcs converged on and docked onto the south edge of Laurentia (early North America), adding new terrane to the continent. About 1,400 Ma, deep masses of granitic magma heated the basement rock and reset the radiometric ages younger than their original crystallization ages (Karlstrom and Bowring, 1988; Condie, 1992; Shaw and others, 2005). In Pagosa Springs, biotite in Precambrian rock was dated by K/Ar at 1,152 \pm 39 Ma on a sample from $1,475 \mathrm{ft}$ depth in a drill hole (Galloway, 1980).

For most of the Paleozoic era, from about 540-300 Ma, the continental Western Interior straddled the equator alternately as a low plain or shallow sea on a wide, sloping continental shelf. Fossiliferous marine sediments accumulated on the shelf. In the Pennsylvanian Period about $300 \mathrm{Ma}$, as the North American and African continents collided, two large island mountain ranges (the Ancestral Rockies) lifted in what is now Colorado. As they lifted, erosion shed thick debris into adjacent basins. However, rocks of the time interval apparently are absent from the quadrangle.

The following history of the quadrangle began after the Paleozoic Era.

\section{Mesozoic Era}

\section{Jurassic Period}

\section{Middle and Late Jurassic Epoch (175-145 Ma)}

Buried sandstone, gypsiferous limestone, and shale of the Wanakah Formation (Todilto Formation in northern New Mexico; Anderson and Lucas, 1992) and Entrada Sandstone were penetrated by petroleum and geothermal exploration drill holes in Pagosa Springs and nearby areas (see cross sections). These formations are made of rock debris eroded from mountains in eastern Nevada and possibly from remnants of the Ancestral Rockies, carried to and deposited in basins by streams and wind. 


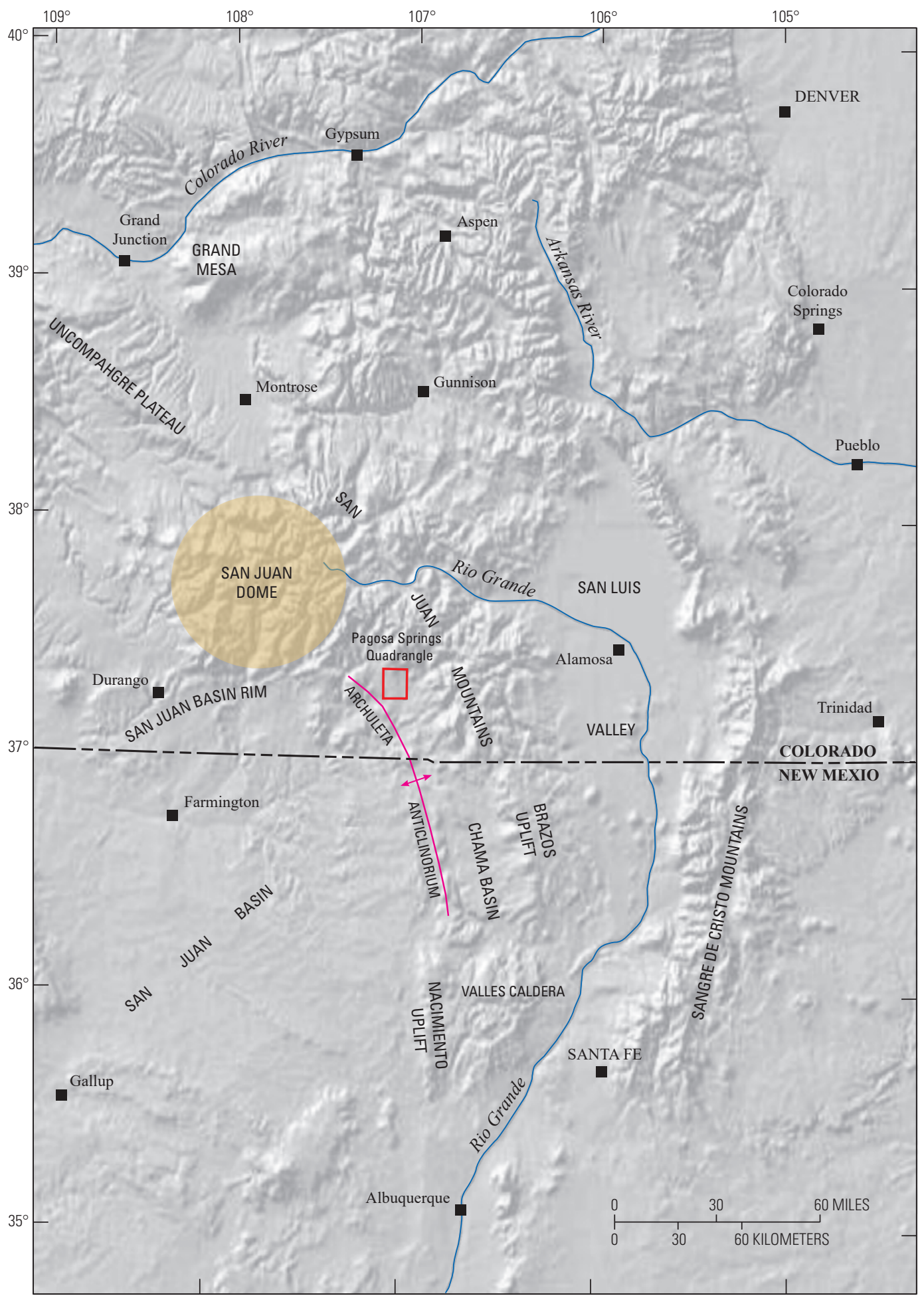

Base from ESRI ArcGis Online, World Shaded Relief Map, derived from $30 \mathrm{~m}$ digital elevation data, accessed August 2017 Universal Transverse Mercator projection, zone 13N North American Datum 1983

Figure 1. Location and setting of Pagosa Springs quadrangle showing outline (red rectangle) of quadrangle. 


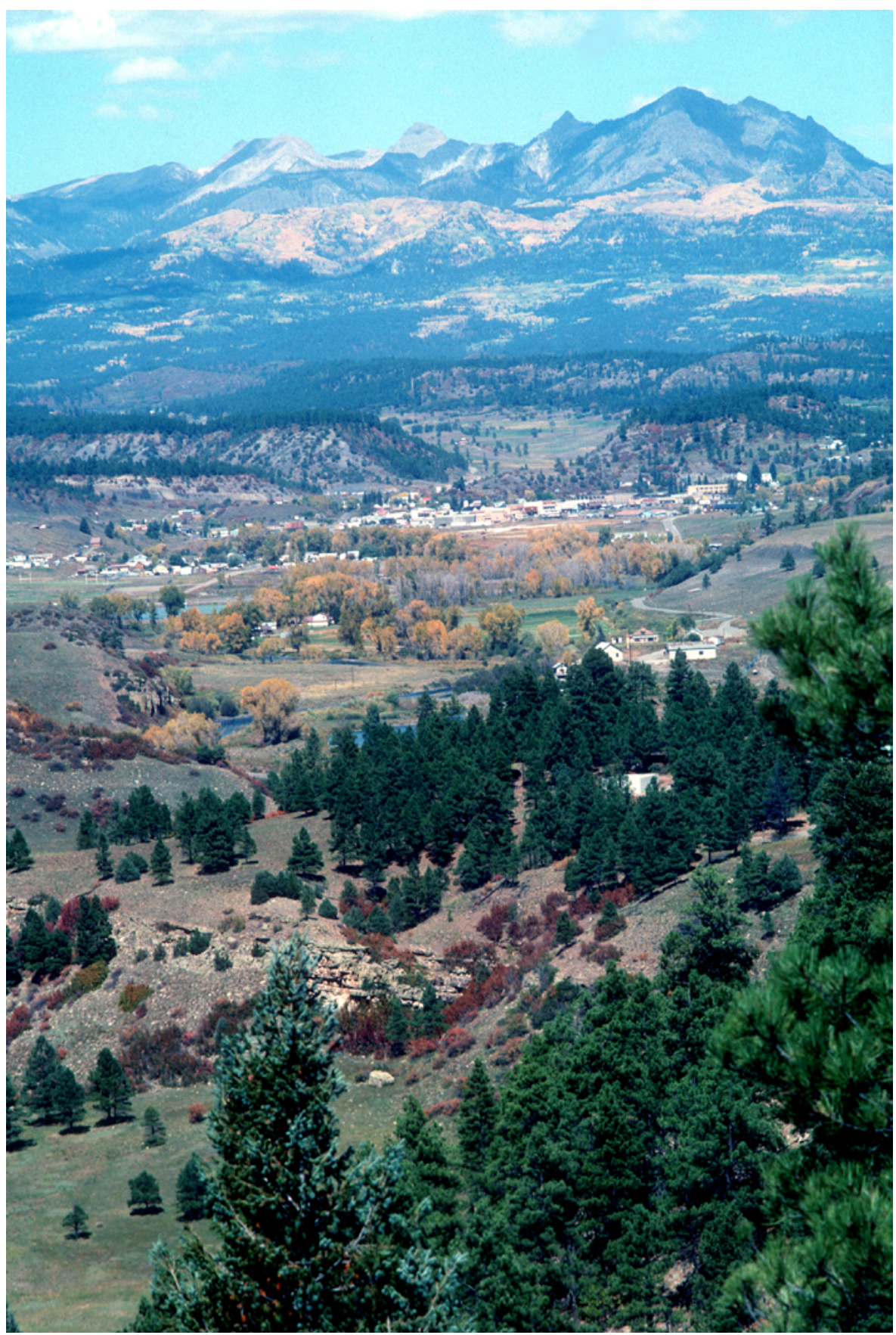

Figure 2. Photograph showing town of Pagosa Springs, Colo. The low terraces are north of town, and Pagosa Peak is on skyline. Taken about 2 miles south of Pagosa Springs, just outside of southern map area border, looking north. Photograph by David Moore, 1980. 
The oldest exposed rock unit, the Morrison Formation $(\mathrm{Jm})$, is made of sediment deposited late in the Jurassic on a vast, low plain. The Morrison Formation underlies the Dakota Sandstone (Kd) in Martinez Canyon (southwest corner of the quadrangle) where talus cover prevented a close study. Drill holes nearby (Galloway, 1980) also record Morrison Formation beneath the Dakota Sandstone, in normal stratigraphic order. The plain on which Morrison sediment accumulated covered the Western Interior (Blakey and Ranney, 2008) from Mexico to Canada, including what is now the eastern Colorado Plateau, Rocky Mountains (not yet formed), and western Great Plains. Rivers flowing from Idaho, eastern Nevada, western Utah, and the Mogollon Highlands in Arizona (Peterson, 1988) brought sediment to the plain. Uniform bedding suggests deposition in sluggish, migrating channels, on mud flats, in swamps and in large shallow, short-lived alkaline or freshwater lakes (Turner and Fishman, 1991) on a semiarid, savannah-like landscape (Kowallis and others, 1998; Turner and Peterson, 2004). Ash erupted from volcanoes in southwestern Arizona settled onto the plain (Dott, 1979). The ash weathered to clay minerals, mostly smectite (bentonite) and illite (Skipp and Aubrey, 1992). The clay and organic matter was oxidized and zeolitized in soil zones, which colored tuffaceous claystone to the characteristic pale hues of tan, maroon, and green. The Morrison at other localities has yielded entire fossil skeletons of sauropods (dinosaurs with "lizard feet") and pterosaurs (flying reptiles) (King and others, 2006).

\section{Cretaceous Period}

\section{Early Cretaceous Epoch (145-100 Ma)}

While streams eroded the land in southern Colorado (Aubrey, 1992), rising sea level began flooding low coastal areas around the Gulf of Mexico, depositing calcareous marine mud on the shelf in southern Arizona, New Mexico, and Texas (Bilodeau and Lindberg, 1983). Simultaneously in Colorado, upper parts of the Morrison Formation were being eroded, evidenced by the regional unconformity beneath the overlying Dakota Sandstone (Cobban and Reeside, 1952; Pipiringos and O'Sullivan, 1978). Early Cretaceous southwestern Colorado was slightly above sea level as was the Western Interior of the continent.

Not until latest Early Cretaceous (about $105 \mathrm{Ma}$ ) did the Western Interior Seaway invade southwest Colorado. Globally, sea levels were rising (Miller and others, 2005), hypothetically caused by large outpourings of lava like the extensive Ontong Java and Manihiki Oceanic Plateaus in the southwest Pacific, or rapid spreading of the mid-Atlantic ridge (Duncan and Richards, 1991; Taylor, 2006); both would displace seawater from ocean basins onto low-lying continental areas. Geographically, Cretaceous rocks indicate that flooding advanced (transgressed) southward from the Arctic Ocean onto the midcontinent, covering areas now occupied by the Rocky Mountains and Great Plains, and westward into north-central Colorado (Weimer and Land, 1972).

\section{Late Cretaceous Epoch (100-66 Ma)}

The sediment composing most local rocks was deposited during the Late Cretaceous. By 100-97 Ma (Aubrey, 1992), the inland sea covered much of Colorado (Gillette and Thomas, 1985) and sediment accumulated on coastal plains and shorelines, forming dunes, deltas, offshore sand bars, and lagoons. These environments shifted landward and seaward repeatedly for the next 30-25 Ma, forming the Dakota Sandstone (Kd) and overlying Cretaceous rocks throughout the midcontinent (Obradovich, 1993; Molennar and others, 2002). Volcanic ash blew in from a tectonically active west edge of the continent. Whereas shell-making organisms living in shallow warm seas in Texas made calcareous mud, reefs, and shoals (Moore, 2010), in Colorado mostly terrigenous clay and sand was deposited on deltas (the Mesaverde Group) and in the inland sea. The clayey sediment would become the Mancos and Lewis Shales. Thin layers of calcareous nannoplanktonic ooze settled on low-energy, deeper central parts of the seafloor and lithified to chalky limestone of the Bridge Creek Limestone and Fort Hays Limestone Members of the Mancos Shale.

As the Western Interior Seaway deepened, older sediments and underlying crust subsided. Marine sediments accumulated layer on layer. The depth of the sea varied as the crust rose or subsided and global sea levels varied (Haq and others, 1987). At its largest, about $600 \mathrm{mi}$ wide, the sea divided the continent into eastern and western land masses. An equable and warm Cretaceous climate (Barron, 1983) nurtured abundant coastal vegetation and marine life in the expansive sea. Marine fauna included fishes, sharks, rays, turtles, large air-breathing reptiles (mosasaurs and plesiosaurs), calcium carbonate shell-forming clams, oysters, single-celled plankton, foraminifera, and coccolithophores (microscopic algae), and various ammonite (cephalopod) species. Crocodiles lived in coastal swamps (Cope, 1885). Depositional conditions were favorable for preserving fossils, and museums worldwide are able to represent the now extinct Cretaceous fauna with diverse and high-quality fossil displays.

Uppermost Cretaceous Kirtland Shale, Fruitland Formation, and Pictured Cliffs Sandstone include economic coal (Carroll and others, 2011) deposits that formed in densely vegetated coastal swamps and mires. These units were eroded from the map area, but presently form the hogback of the San Juan Basin about 20 mi southwest of Pagosa Springs.

\section{Cenozoic Era}

\section{Paleogene Period (66-23 Ma)}

\section{Paleocene, Eocene, and Oligocene Epochs}

Near the close of the Mesozoic Era, the sea retreated from Colorado for the last time. Concurrently, the Rocky Mountains began to rise (Laramide orogeny) (Fassett, 1974; Cather, 2003). Although no mountains rose in the Pagosa Springs quadrangle, not far north and east, the Laramide, San Luis highland was rising where the Uncompahgre Plateau, eastern 
San Juans, and San Luis Valley are today (fig. 1; Tweto, 1975). The Nacimiento uplift also came up 90 mi south (Baltz, 1967). Both highlands sourced sediment to San Juan Basin. Other nearby Laramide uplifts are the Needle (San Juan dome) and Brazos (Tusas) Mountains (Muehlberger, 1967). The early Paleocene Archuleta anticlinorium, which is in part a broad, north-trending uplift, extends into the Pagosa Springs quadrangle (fig. 1). This feature is likely related to the Laramide uplifts mentioned above, and it extends south of the map area where it may connect with the Nacimiento uplift about $90 \mathrm{mi}$ to the south.

The Laramide orogeny probably was caused by continental-scale, east-west compression driven by thermal convection in Earth's upper mantle (Dickinson and Snyder, 1979; Livaccari and others, 1981). Dickinson and Snyder (1979) and Bird (1988) posited that as the Pacific oceanic crust, the Farallon plate, subducted under west-moving North America, it remained flat at a shallow depth, "scraping" the base of continent and far eastward into it (roughly $600 \mathrm{mi}$ ), making east-west directed forces of friction and compression. According to Liu and others (2010), a large oceanic plateau riding on the Farallon plate caused vertical movements that may explain the Late Cretaceous marine flooding and Paleogene mountain building. The forces pushed up basement-cored blocks on steep faults, making the north-trending modern Rocky Mountains. The forces possibly also folded rock layers of the Archuleta anticlinorium. As the ranges emerged, basins among them, including the San Juan Basin, subsided and received Paleogene sediment. These hypotheses also suggest a period of tectonic quiescence ("relaxation") followed the compression, causing regional east-west extension, which may have formed the Stinking Springs fault and other faults, $2-4 \mathrm{mi}$ west of town (see map).

Later, during the tectonically quiet late Eocene Epoch, streams eroded a wide, low-gradient bedrock surface in southern and central Colorado (Epis and Chapin, 1975).

Astounding events followed this quiescence. Titanic volcanic eruptions occurred northeast of Pagosa Springs 37-24 Ma (mostly in the Oligocene Epoch). Two phases are recognized. An early phase (37-30 Ma) erupted andesitic and intermediate composition lavas and volcaniclastic debris that composes the Conejos Formation (Steven and others, 1974). The later phase, 30-24 Ma, saw colossal eruptions of ash-flow tuffs exploded from stratovolcanoes so huge ("supervolcanoes") that masses of rock collapsed into underlying magma reservoirs, making 15 large calderas (Steven and Lipman, 1976; Lipman, 2006; Bachmann and others, 2000). These explosions were some of the largest known in Earth history. Dense, fiery clouds of ash and particles raced outward, burying large parts of southwest Colorado and covering older volcanic rocks that overlie the late Eocene erosion surface mentioned above (Dunn, 1964); residual heat welded and fused the ejecta to hard, thick tuff layers of the San Juan Mountains.

Oligocene intrusive rock units at Jackson Mountain, about 10 mi northeast of Pagosa Springs, were dated at 25.1 Ma based on U-Pb ages obtained from zircons (Gonzales, 2015).

\section{Neogene Period (23-2.6 Ma)}

\section{Miocene and Pliocene Epochs}

During the late Neogene, the Western Interior, Colorado Plateau, and western Great Plains were lifted (epeirogenic uplift) (Eaton, 2008). Precisely when and how much is debated; some attribute the uplift to the earlier Laramide orogeny (Pederson and others, 2002). Others believe that after Laramide uplift of individual mountain ranges, the entire region, including basins, was lifted even more (McQuarrie and Chase, 2000). Notwithstanding the debate, evidence for regional uplift is apparent. Cretaceous marine sediments in the quadrangle and surrounding states stand more than $6,000 \mathrm{ft}$ above sea level. Empowered by the uplift, rivers cut deeply into Precambrian basement rock. Examples include the Black Canyon of the Gunnison and Royal Gorge of the Arkansas Rivers; Piedra River canyon, northwest of the map area, is another nearby example. The Colorado River has cut 5,200 ft below the 10 Ma-old basalt cap on Grand Mesa (U.S. Geological Survey, 1966; Scott and others, 2001). McMillan and others (2006) believe that intermountain basins first filled with sediment during Oligocene slow subsidence, followed by uplift in late Miocene that continued from about 7 Ma to the present. They posit that regional uplift followed the crustal extension cited above, driven by isostatic forces (slow flow of upper mantle rock responding to loading of the crust above) and cited east-tilted Pliocene deposits on the western Great Plains as support (McMillan and others, 2002). Eaton (2008) proposed domal uplift over buoyant mantle anomalies caused by Neogene intrusion of hot magma under the Rockies.

\section{Quaternary Period (2.6 Ma-Present)}

\section{Pleistocene and Holocene Epochs}

North American continental glaciers may have begun about 2.5 Ma, evidenced by glacial deposits in oceanic sediment (Shackleton and others, 1984). However, alpine valley glaciers formed much later in the San Juan Mountains based on end-moraines about 300-140 ka (thousand years) old in the Animas River Valley at Durango (Scott and Moore, 2007). Steven and others (1974) stated that younger moraines formed roughly after $140 \mathrm{ka}$ in the Piedra River headwaters only $7 \mathrm{mi}$ north of the quadrangle.

Traditionally throughout the Rockies, field studies by geologists have found and named two major glaciations (Blackwelder, 1915). The older, Bull Lake, was thought to have begun about $200 \mathrm{ka}$ and ended with the Sangamon warm interglacial 130-127 ka (Fullerton and others, 2004). The younger, Pinedale, was about 30-14 ka, peaking about 20-18 ka, concurrent with maximum extent of the Wisconsin continental ice sheet (Richmond, 1965). More specific ages have resulted from cosmogenic nuclide dating; a few examples are cited here. Benson and others (2005) measured ${ }^{10} \mathrm{Be}$ surface-exposure ages of boulders on crests of Pinedale end moraines in southwest Colorado; they concluded that glacier 
retreat began about $16.8 \pm 0.3 \mathrm{ka}$. Leonard and others (2017) obtained ${ }^{10} \mathrm{Be}$ surface-exposure ages from moraine boulders and ice-polished outcrops of about $21 \mathrm{ka}$ until 17-16 ka, the time when Pinedale valley glaciers were at maximum extent in the Sangre de Cristo Mountains. ${ }^{10}$ Be surface-exposure ages of Pinedale terminal moraines in the upper Arkansas River Valley reported by Schweinsberg and others (2016) averaged $21.8 \pm 0.7 \mathrm{ka}$. The ages vary owing to preexisting factors such as snow cover, rock erosion, and sample site location. Interested readers are referred to the published work.

We mapped possible glacial deposits mixed with definite landslide deposits (diamicton, Qd) in the northeast corner of the quadrangle. As climate warmed and the last alpine glaciers melted, volcanic-clast-rich stream gravel (outwash) washed southward into the quadrangle.

\section{Surficial Deposits}

\section{Gravel}

Stream gravel is present in narrow deposits in modern channels, for example, along Fourmile Creek. These waterworn gravels are derived mostly from volcanic rock in the San Juan Mountains and were rounded by abrasion during stream transport. Layers of river gravel armor the underlying shale, slowing erosion of the river bed, and with time, the landscape inverts - parts that were low become high, and vice versa. Shale not covered by gravel is eroded deeply. This process forms a succession of vertically elevated gravel-capped benches (fluvial terraces) along modern stream channels.

The gravel here is mined for road base. The walls of a gravel pit (active in 2015) on Oakbrush Hill (left center of map area) expose coarse, rounded clasts of volcanic river gravel (Qtg5, fig. 3). Similar deposits compose the Qg, Qtg1-4, Qop, and Qob units, which were all made by south-flowing streams in former channels; their remains now stand at various heights. The gravel deposits flanking Fourmile Creek (Qop and Qob, northeast part of quadrangle) are glacial outwash and some of the other gravels may also be outwash. Boulders as large as $3 \mathrm{ft}$ in diameter within the deposits suggest glacial meltwater discharges were more powerful than the discharges of existing and precursor streams of the present interglacial (Holocene, approximately during the last 12,000 years). Higher still in the landscape is an older outwash gravel deposit (Qob) that flanks McCabe and Fourmile Creeks. Besides the outwash, some high, hill-capping gravel (Qpg) in the north part of the quadrangle is pediment gravel. Others are landslide and debris-flow deposits (Qdf).

Erosion acting over thousands of years sculpted the vertical sequence of gravel-veneered fluvial terraces. The Qtg1 deposits are only $10 \mathrm{ft}$ or less above modern streams. In the uplifted map area, streams have cut downward to modern levels, abandoning former higher stream levels that are now evidenced by the fluvial terrace remnants (Qtg1-5). Relatively high (older) gravels, for example Qtg4, have advanced (and thickened) soil development — an earmark of weathering for thousands of years - which includes blocky or prismatic structure in an oxidized, red-brown clayey B soil horizon that typically has whitish, calcium carbonate built up in its lower part. Recognition of well-developed soils and the heights of old terrace deposits stem from the study of geomorphology and soil science (Shroba and Birkeland, 1983).

The highest terrace gravel Qtg5 is on Oakbrush Hill (elevation $8,069 \mathrm{ft}$; southwest part of map area). It may be older than the Bull Lake outwash gravel (Qob), because of its greater height (430-440 ft above Martinez Creek). Bull Lake-age gravels (Qob, Qtg4?) are about 200-140 ka in age (Hall and Michaud, 1988; Schweinsberg and others, 2016); Pinedale-age gravels (Qop, Qtg3?) about 30-14 ka; and postglacial gravels (Qtg2, Qtg1, Qal) are $<14$ ka (fig. 4; Pierce, 2003). The names derive from alpine glaciations named in the Wind River Mountains, Wyoming (Blackwelder, 1915; Richmond, 1965).

\section{Other Deposits}

Loess (wind-deposited silt) was not mapped separately because it is thin and spotty. Loess is commonly mixed with sheetwash alluvium and is reddish-brown silt, silty clay, and clayey silt that veneers nearly level land, chiefly on terrace surfaces. In the northeast part of quadrangle, a poorly exposed surficial deposit of uncertain origin is mapped as diamicton (Qd); it includes old gravels, which might be glacial or glaciofluvial in origin (late middle Pleistocene?), that are mixed with and modified by younger landslide deposits (Holocene to latemiddle Pleistocene?). Other scattered surficial deposits include alluvial-fan, debris-flow, pediment gravel, and landslide deposits as well as talus, colluvium, sheetwash alluvium, and travertine. Soils and surface-capping residuum are widespread, but they were not mapped. In general, deposits were mapped where they exceeded $4-5 \mathrm{ft}$ in. thickness.

\section{Structure}

Sedimentary rock layers dip gently northeast as part of the broad northeastern flank of the northwest-trending Archuleta anticlinorium (see fig. 1). High-angle faults cut and offset the Cretaceous layers locally. Two prominent northwest-trending faults cut rock layers in the southwest part of the quadrangle. The longer one, the Stinking Springs fault (see map), extends $6 \mathrm{mi}$; the other extends $2.5 \mathrm{mi}$. Both are high-angle normal faults. Bedding is offset approximately $480 \mathrm{ft}$ along the Stinking Springs fault, measured in $\mathrm{SW}^{1 / 4}$, NE $1 / 4$, sec. 22, T. 35 N., R. 2 W. The Dakota Sandstone (Kd), the Graneros Shale Member of the Mancos Shale (Kmgr), and underlying units are down-dropped on the southwest side of these two faults. 


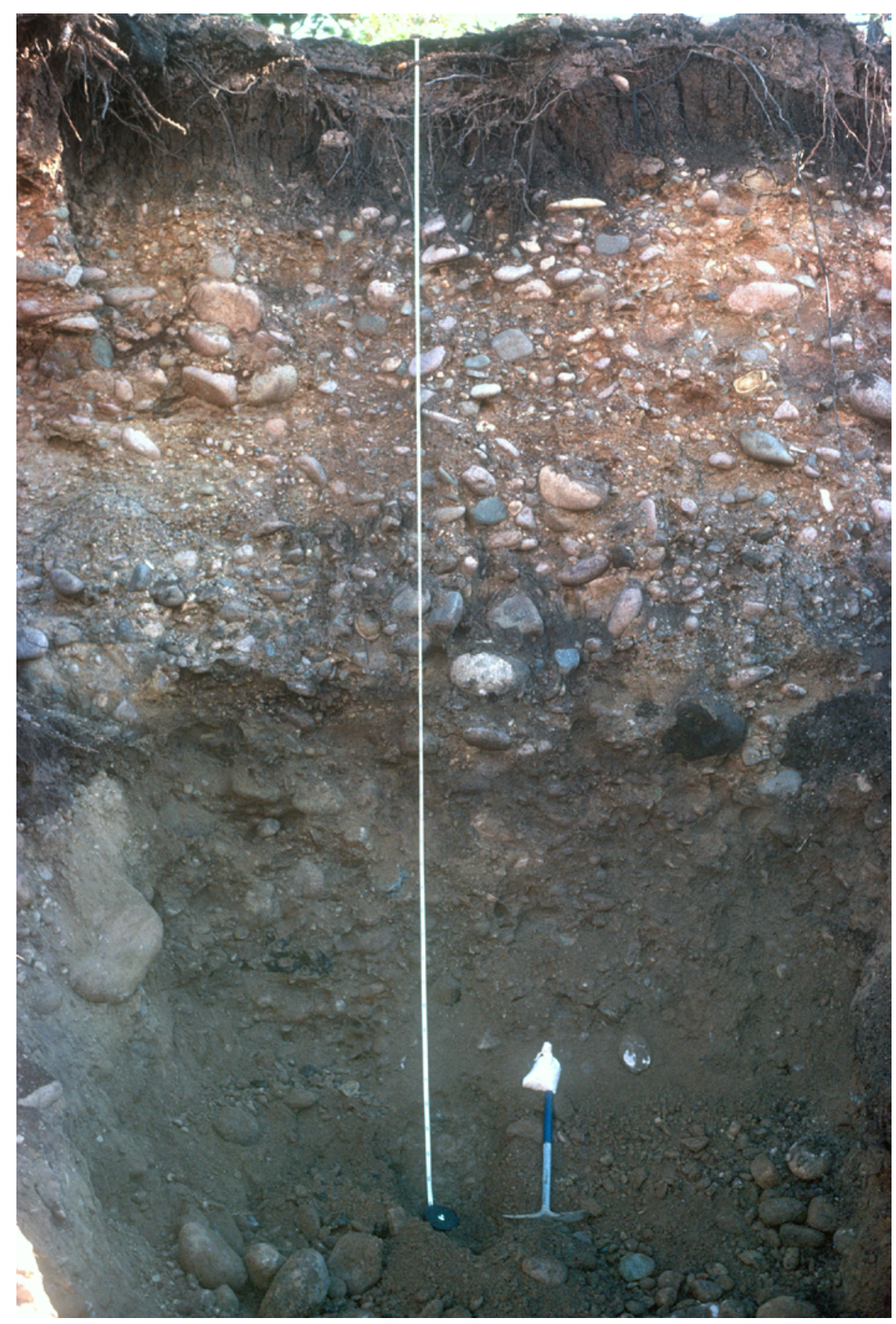

Figure 3. Oldest fluvial terrace gravel (Qtg5) in gravel pit, on Oakbrush Hill in the map area, section 6, Township 35 N., Range 2 W.; thickness $18 \mathrm{ft}$. Pick is $2 \mathrm{ft}$ in length. Photograph by David Moore, 1980. 


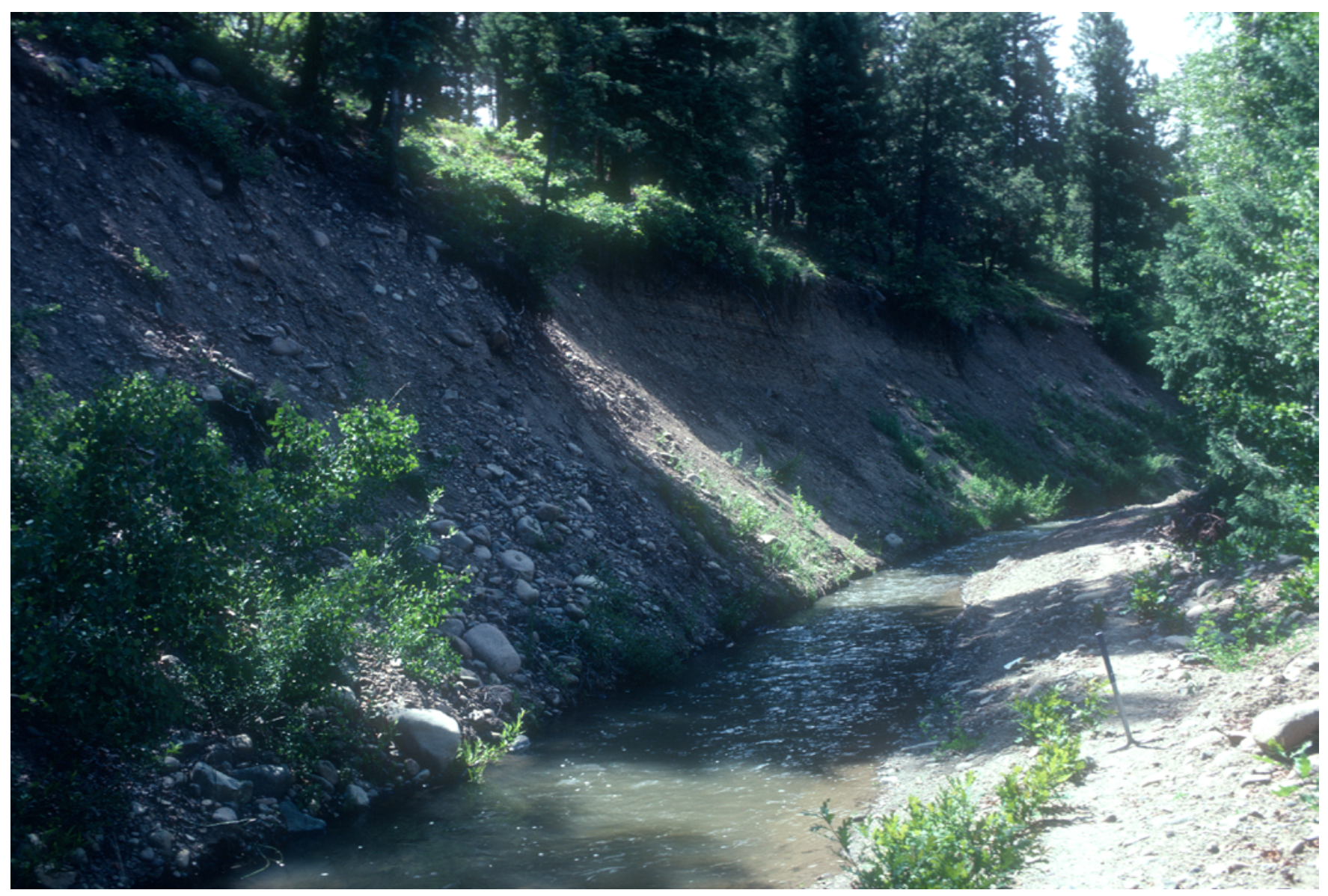

Figure 4. Pinedale glacial outwash (Qop), 15-25-foot-thick, overlying shale of the Mesaverde Group (Kmv) exposed at Mesa Ditch in the northeast part of the Pagosa Springs 7.5' quadrangle. Terrace is about $140 \mathrm{ft}$ above the nearby Fourmile Creek. Boulders on the shaded slope have cascaded downslope from outwash above; they mantle gently dipping shale exposed in slope in right-central part of photo. Photograph by David Moore, 1980.

The Archuleta anticlinorium is a broad, north-trending arch of crustal rock that includes numerous folds and faults in northeast New Mexico and several folds and faults in southern Colorado. It is a Laramide structure of early Paleocene age (Cather, 2003), perhaps modified later by extensional forces. The anticlinorium defines the northeast margin of the San Juan Basin and its broad eastern limb extends into the quadrangle and is expressed by the gentle east dip of Cretaceous rock units throughout most of the quadrangle. Smaller scale anticlines, synclines, and a monocline are mapped mostly in the northwestern part of the map area and might be related to the anticlinorium. However, most of these mapped folds are northeast-trending and a direct relationship to the north-trending anticlinorium is not obvious. According to Baltz (1967), the Archuleta anticlinorium formed at the same time as the Nacimiento uplift farther to the south.

\section{Cross Sections and Subsurface Information}

The map sheet includes three cross sections that portray structural and stratigraphic relations in the subsurface across the map area. The broad arching of strata and faults discussed above, and the stratigraphy described below, are depicted in these sections. Together with the stratigraphic column of the map area (fig. 5), they provide glimpses of subsurface relations beneath the Pagosa Springs quadrangle. The cross sections are constrained by surface exposures of contacts between rock units, by measured bedding orientations of the units, and by depths to the rock-unit contacts in the subsurface as recorded in drill-hole data.

The five wells shown in the cross sections (one shown in two cross sections) are the only wells in and nearby the map area that have recorded information regarding the rock units penetrated during drilling. Data for the deep geothermal test well in the southeast corner of the quadrangle (see $\left.C-C^{\prime}\right)$ are 


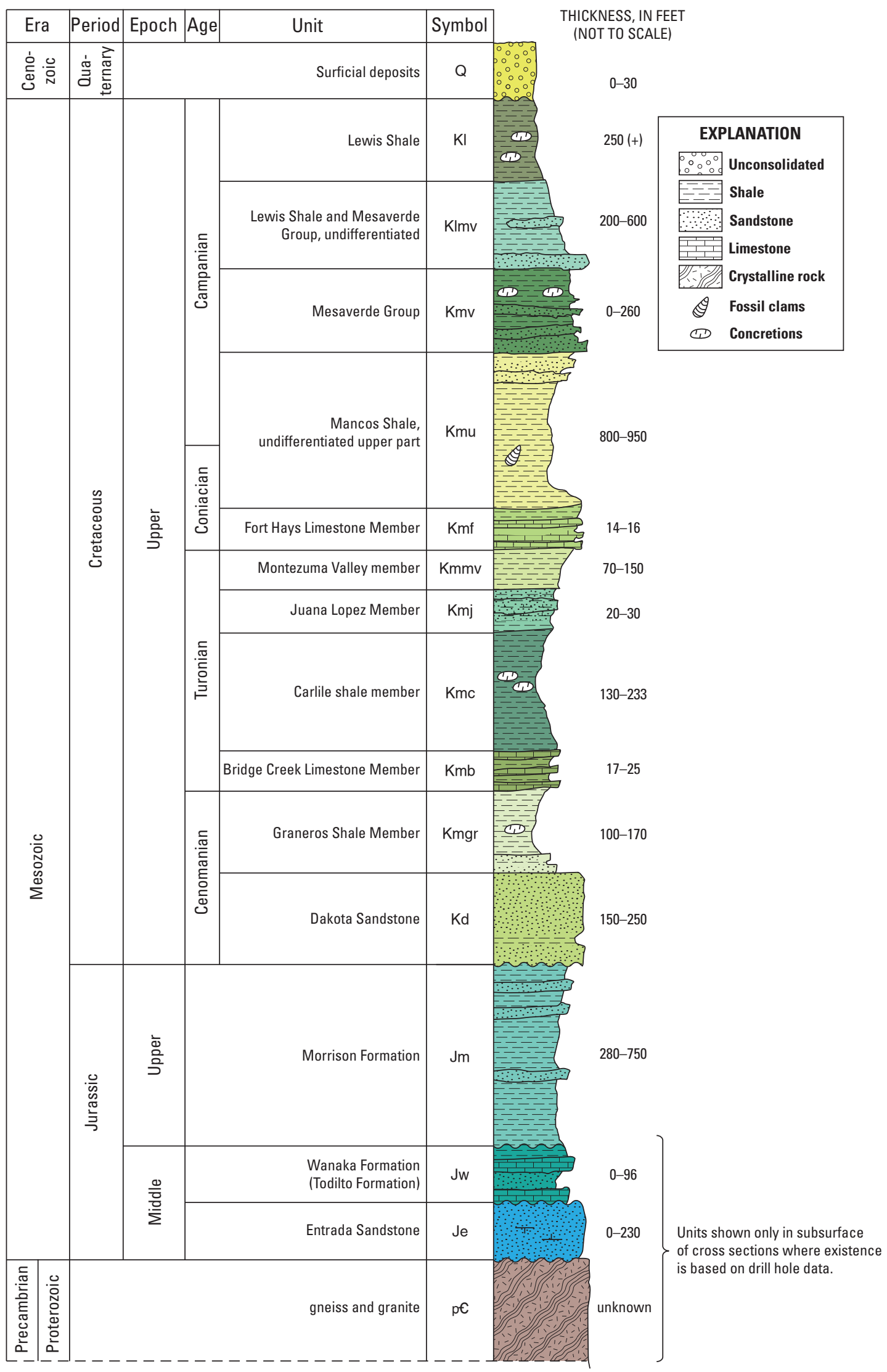

Figure 5. Stratigraphic column showing map units of the Pagosa Springs $7.5^{\prime}$ quadrangle. Modified from the drill hole based stratigraphic column shown in Galloway (1980). 
available in Galloway (1980); drill-hole data for the other wells shown in the cross sections were acquired from the Colorado Oil and Gas Conservation Commission (COGCC) website (http://cogcc.state.co.us/maps.html\#/gisonline). Some of the drill holes shown in the cross sections extend deep enough to penetrate older sedimentary and igneous-metamorphic (crystalline) rock units that do not crop out at the surface in the quadrangle (discussed below).

Other drill holes shown only on the map (7 wells), those that are not also shown in the cross sections, either to our knowledge have no record or their records on the COGCC website do not specify the rock units penetrated in the drill hole. Wells that have no record (4 wells) are labeled "NR" on the map. Wells shown on the map whose records lack rockunit information are Cloman 1, Adios-Dinero 1, and Adios Dinero 2.

Drill holes that were used to constrain subsurface relations in the cross sections are shown and labeled on the cross sections and on the geologic map. There is one exception; the Strat no.1 well is shown projected into the southwest end of cross section $A-A^{\prime}$. This well is located about $1 \mathrm{mi}$ northwest of the $A-A^{\prime}$ cross section intersection with the west map border and consequently, it is outside of the map area and not shown on the map. The Strat no. 1 well, the H.R. Macht no. 1 well in the northeast part of the map area, and the CGS Test Well P-1 in the southeast corner (downtown Pagosa Springs), provide very significant subsurface information in that they all penetrate beneath the Jurassic and Cretaceous sedimentary rock units exposed in the quadrangle and bottom in significantly older underlying Precambrian crystalline rocks (see cross sections).

The Jurassic Morrison Formation ( $\mathrm{Jm})$ is the oldest rock unit exposed in the map area and data from the three deep wells mentioned above indicate that the Morrison overlies differing older rock units at depth. In the drill hole in the northeastern part of the map area (H.R. Macht no. 1), the Morrison Formation unconformably overlies Precambrian crystalline rocks at depth (see $B-B^{\prime}$ ). However, in the drill hole just west of the map area (Strat no. 1) and in the drill hole in the southeast corner of the map (CGS Test Well P-1), the Morrison Formation overlies older Jurassic sedimentary rock units consisting of the Wanakah Formation (Todilto Formation in northern New Mexico) and the underlying Entrada Sandstone; the Entrada in turn unconformably overlies Precambrian crystalline rocks near the bottom of these two drill holes (see $A-A^{\prime}$ and $C-C^{\prime}$ ). For the map area, the existence of the Wanakah Formation, Entrada Sandstone, and Precambrian crystalline rocks is known only from the subsurface drill-hole data of these three wells. These subsurface units are shown in the cross sections near the deep wells that penetrate them, but their possible lateral continuations are not inferred elsewhere in the cross sections where subsurface information is lacking.

The lines of the cross sections $\left(A-A^{\prime}, B-B^{\prime}\right.$, and $\left.C-C^{\prime}\right)$ intentionally intersect the locations of some of the wells shown on the map. This allows the subsurface drilling information from these intersected wells to be directly represented at those intersected localities in the subsurface of those cross sections. Cross sections $A-A^{\prime}$ and $B-B^{\prime}$ also show wells that are projected into the lines of these cross sections from well sites that are as much as $1.75 \mathrm{mi}$ from the line of the cross section. These wells are projected along the strike of the strata and perpendicular to the line of the cross section. The relative positions of the tops and bottoms of projected wells are adjusted in the cross sections based on the elevation of the topographic surface at the well site relative to the surface elevation of the location where the well projection intersects the line of the cross section. These projected wells provide constraints on the relations and thicknesses of rock units in the subsurface at these localities in the cross sections. We consider these projections of well information over distances of less than $2 \mathrm{mi}$ to be reasonable and perhaps the best method available for extrapolating rock-unit relations and thicknesses in the subsurface at these cross-section localities. In the cross sections, intersected wells are portrayed as solid lines in the subsurface and projected wells are shown as dashed lines.

\section{Acknowledgments}

During field studies, numerous landowners graciously granted access permissions to their land. Jan Tulley (Pagosa Springs Town Hall) helped locate data related to the town's geothermal project. We thank the following geologists for their thorough and insightful technical reviews that significantly improved the map and report: Orin Anderson (resident of the Pagosa Springs area and retired from the New Mexico Bureau of Mines and Geology), Margaret Berry (USGS), and Chris Carroll (formerly with the Colorado and Wyoming Geological Surveys). This map was first digitized by Chris McGuire using a program created by Van Williams (USGS). Darren (Paco) VanSistine (USGS) was responsible for updating the initial digital version of the map data and topographic base and for the creation of the geodatabase and metadata for the digital map data; these are published and available on ScienceBase (Moore and others, 2018). Jeremy Havens (USGS) assisted with initial drafts of some of the figures. Julie Herrick (USGS) provided the geologic names review, was responsible for final editing and layout of the map sheet and pamphlet, and for many aspects of the final figures shown in the pamphlet and on the map sheet. Any errors that remain are those of the authors. 


\section{DESCRIPTION OF MAP UNITS}

\section{SURFICIAL DEPOSITS}

Bases of deposits are not exposed; thickness estimated.

\section{ARTIFICIAL FILL}

af

Qg

Qtg1

Qsw
Fill (modern) —Earth and rock fragment in dams; crushed aggregate as fill and base material for airport runways; thickness $3-30 \mathrm{ft}$

\section{PRECIPITATED ROCK}

Travertine (late Holocene) - Limestone, calcium carbonate $\left(\mathrm{CaCO}_{3}\right)$ precipitated from warm spring water; very pale orange, white, weathers light gray and light brown, finely crystalline $\mathrm{CaCO}_{3}$, fibrous or reed-like, porous, "honeycomb-like" rock, in places is cavernous, thickly laminated, densely layered, or concretionary; has built up a large domal structure on the inside of a meander along the San Juan River in Pagosa Springs. Forms 6-ft-high mounds of accumulated carbonate layers that have silt-size, dark-brown organic inclusions. Total thickness unknown, but at least several ft thick along San Juan River where base is covered

\section{ALLUVIAL DEPOSITS}

Sheetwash alluvium (Holocene) - Widely present on low, nearly flat parts of shale bedrock near the Dakota Sandstone-Graneros Shale Member contact. Common in valleys and around reservoirs; only the thickest deposits were mapped; an example in NE 1/4 sec. 22, T. 35 N., R. 2 W. is very dark brown massive clay and dark grayish brown silt; 30-50 percent coarse sand-sized shale fragments; sticky when wet and hard when dry; mixed with sandstone fragments near faults; unit 2-5 ft thick

Alluvium (Holocene) — Gravel and calcareous sand and silt. McCabe Creek alluvium is typical: grayish-brown, very dark grayish brown, and black, clayey, lithic sand; local lenses of reworked shale or limestone fragments and rounded volcanic porphyritic tuff pebbles and cobbles; lithic sand-size grains of shale, siltstone, limestone, volcanic rock, and $<5$ percent quartz. The alluvium is massive, crudely stratified; sticky when wet, hard when dry; commonly contains shells of small land snails; locally $2 \mathrm{ft}$-thick basal gravel composed mostly of shale clasts. Dutton Creek alluvium is about 80 percent Dakota Sandstone subangular blocks 2-24 inches (in.) and 20 percent rounded volcanic tuff pebbles and cobbles. It is covered by 1-2 ft thick, humic dark gray silty clay. Map unit includes a few low river terrace deposits about $10 \mathrm{ft}$ or less above streams; unit thickness 6-12 ft; San Juan River deposit may be as thick as $24 \mathrm{ft}$

Gravel deposit (Holocene to late Pleistocene) - Small, isolated gravel remnants that cap benches and hills in places at various heights above streams, generally 80-160 ft. Likely correlative with a few of the units in the terrace gravel sequence, but some are thin, nonbedded lag gravels. Unit was mapped separately because these isolated gravel occurrences could not be confidently correlated with specific terrace gravel units. Unit includes waterworn, volcanic porphyry pebbles and cobbles and locally includes angular clasts of Dakota Sandstone. Small deposits capping small hills just north of Pagosa Springs are 85 percent blocky, Dakota Sandstone cobbles and 15 percent rounded, volcanic porphyry pebbles and cobbles. Thickness of unit 1-5 ft

Fluvial terrace gravel, youngest (Holocene) - Unit consists of about 65 percent blocky (slightly rounded edges) Dakota Sandstone cobbles, 30 percent well-rounded volcanic porphyry pebbles and cobbles, and 5 percent rounded granite, shale, and quartzite clasts. Unit has a grayish brown clayey sand matrix; forms a terrace $20 \mathrm{ft}$ above San Juan River near downtown Pagosa Springs. Thickness 3-6 ft 
Qtg2

Qtg3

Qtg4

Qtg5

Qfy

Qfo

Fluvial terrace gravel, young (late Pleistocene) - Similar to other terrace-gravel units in being composed primarily of Dakota Sandstone and volcanic porphyry clasts in clay-sand matrix. West and south of Dutton Creek (sec 7 and 8, T. 35 N., R. 2 W.), unit consists of about 90 percent slightly rounded cobbles and boulders of Dakota Sandstone and 10 percent well-rounded cobbles and boulders of volcanic porphyry in a brown, clayey sand (loamy) matrix; many clasts deeply weathered and unit is covered by slope wash (1-4 ft thick) that is very dark, grayish brown clayey silt and locally capped by soil that includes a dark brown 2-ft-thick B horizon. Forms terrace $50 \mathrm{ft}$ above San Juan River at highway bridge (Highway 160) over river in town and a terrace 35-40 ft above Dutton Creek. Unit ranges from about 5 to $15 \mathrm{ft}$ thick near Dutton Creek

Fluvial terrace gravel, intermediate age (late Pleistocene) - Rounded pebbles and cobbles of volcanic porphyry containing less than 2 percent blocks ( $0.3-1.5 \mathrm{ft}$ in diameter) of Dakota Sandstone in sandy matrix; many clasts deeply weathered in a yellowish-brown sticky sandy clay matrix; upper 3-6 ft is yellowish-brown clayey silt (loess?). Surface soil developed in the silt is typically well-developed with a reddish-brown B horizon, the lower part of which is carbonate-enriched to as much as stage III carbonate morphology (Gile and others, 1966). Soil development suggests intermediate age. Terrace surface is $160-180 \mathrm{ft}$ above San Juan River (east of town) and 160-180 ft above Dutton Creek (near center of map area). Unit may be correlative in age with Pinedale outwash (Qop) based on their similar height in the landscape and weathering characteristics. Unit generally 4-8 ft thick with sharp contact on black shale; 9-11 ft thick near confluence of Dutton and Martinez Creeks in southwest part of map area (sec. 18, T. 2 W., R. 35 N.)

Fluvial terrace gravel, old (late middle Pleistocene) — Rounded to subrounded pebbles and cobbles composed mostly of volcanic porphyry (rhyolitic?) in sandy silty matrix. Forms river terraces 300-330 ft above San Juan River and $330 \mathrm{ft}$ above Martinez Creek. Essentially like the Qtg3 unit in composition, clast size, soil development, and thickness. Unit may be correlative in age with Bull Lake outwash (Qob) based on their similar height in the landscape and weathering characteristics. Thickness not measured, but may range from about $5-15 \mathrm{ft}$

Fluvial terrace gravel, oldest (late middle Pleistocene) - River terrace gravel $420 \mathrm{ft}$ above San Juan River (east of town); 430-440 ft higher than Martinez Creek (on Oakbrush Hill, west-central part of map). Matrix-supported, rounded, mainly volcanic porphyry and minor quartzite cobble gravel; matrix is dark-yellowish-brown, mostly poorly sorted, silty medium-grained sand and minor clay; crude bedding; lenticular interbeds of cemented to unconsolidated pebbly sand; unit commonly covered by $2-4 \mathrm{ft}$ of silty loess and sheetwash alluvium. At Oakbrush Hill (east half of sec. 6, T. 35 N., R. 2 W.), an active gravel pit revealed that clasts in this deposit vary widely in size; boulders $>2 \mathrm{ft}$ in diameter are 10-20 percent of deposit, boulders $\leq 1 \mathrm{ft}$ in diameter are 5-15 percent, cobbles are 15-25 percent, pebbles 20-30 percent, and sandy-silty matrix is about 20 percent; $\leq 10$ percent of clasts are deeply weathered and crumbly. Soil at top of unit on Oakbrush Hill is well developed with dark-brown silty, friable, A horizon ( 9 in. thick); dark-yellowish-brown silty AB horizon (6 in. thick); and strong brown silty-clay, plastic B horizon with strong angular blocky soil structure (12-18 in. thick). Typical thickness range of unit is about 6 to $22 \mathrm{ft}$, but about $30 \mathrm{ft}$ thick at south edge of Oakbrush Hill where it overlies black shale on a sharp basal contact

Fan alluvium, young (Holocene) - Generally pale-brown and dark yellow brown pebbly sand, silt, and clay. Mapped along and near base of some slopes flanking active channels; surface soil is minimally developed, suggesting relatively young age. Bedding not exposed. Thickness 1-6 ft

Fan alluvium, old (late Pleistocene) - Exposed east of San Juan River (NE 1/4 sec. 24, T. 35 N., R. 2 W.) and near Hidden Valley. Locally overlies Qob and Qtg3. Dark gray and grayish brown silty clay that is sticky and plastic; contains abundant, small pieces of very dark gray fissile shale and contains $2-5$ percent rounded volcanic cobbles and pebbles. Unit caps low ridges and surfaces above and isolated from active channels and typically has moderately developed soil; elevated position in landscape and soil development indicate unit is older than Qfy. Although old in form, may periodically receive 
new thin layers of sediment on surface from sheetwash events. Thickness near edge of deposit about $4 \mathrm{ft}$, thickens to about 12 or $18 \mathrm{ft}$ in central part of deposits

Pediment gravel deposit (late and middle Pleistocene?) - Rounded gravel mostly of volcanic porphyry rock and minor dark, crumbly mafic rock, in a sand matrix; clasts mostly $12-18$ in. diameter, but generally range from $<1$ in. to about 30 in. diameter; commonly thinly veneered by very dark grayish brown silt (loess?). Forms gently south-sloping, nearly flat-topped remnants of water-transported gravel on relatively small, high interfluves, on foothills in northern third of map area (about 20 separate locations). Unit mapped at various heights above active channels, suggesting deposits are remnants of pediments of differing ages. The deposit on Coyote Hill (west-central part of map, elevation 8,452 ft, NW 1/4 sec. 30, T. 36 N., R. 2 W.) has a weak soil profile and is $700 \mathrm{ft}$ higher than adjacent Martinez Creek; it is the highest and oldest pediment gravel and it may be the oldest Pleistocene deposit in the map area; however, only moderately developed soil profile, thin loess, and poor exposure suggest its surface is actively being eroded. Rock types include cobbles and boulders of dark purple porphyrytic, welded, ash-flow tuff; few greenish cobbles and pink, coarse-grained porphyry; few dark mafic rocks; weathering rinds on clasts $0.019-0.058$ in. thick; many rocks pitted or partly disintegrated, indicating a long time of surface exposure. At Coyote Hill, thickness ranges from $25 \mathrm{ft}$ to possibly $35 \mathrm{ft}$ at its south end. Average thickness of unit in map area 6-15 ft

\section{GLACIAL AND GLACIOFLUVIAL DEPOSITS}

Qop

Qob

Qk

Pinedale outwash (late Pleistocene) - Rounded clasts of volcanic porphyry in a sand matrix; contains unusually large rounded boulders. Presumed source was meltwater from a former valley glacier in the headwaters of Fourmile Creek where glacial cirques are preserved. Forms terrace about 140-150 ft above Fourmile Creek, a height above the creek that implies a late Pleistocene age. Thickness 10-25 ft

Bull Lake outwash (late middle Pleistocene) - Rounded small cobbles in a clayey sand matrix that is 10-20 percent of deposit. Remnants of this deposit extend relatively continuously from the north edge of the map area about $7 \mathrm{mi}$ south to $<1 \mathrm{mi}$ north of town of Pagosa Springs. Presumed source was meltwater from former valley glacier in headwaters of Fourmile Creek north of quadrangle where glacial cirques are preserved. Measured and described in a gravel pit in SW 1/4, NW 1/4, sec. 26, T. 36 N., R. 2 W.; rounded volcanic porphyry pebbles, cobbles, and few boulders, sandy gravel and gravelly sand, clayey and silty very fine quartz and lithic sand, brownish yellow matrix. Predominant diameter of rounded volcanic clasts is $2-12$ in.; one large rounded cobble of very coarse granite was seen. Distinguished from Qop, principally by its higher position in landscape and by more mature soils that locally cap it. Qob terrace remnant just north of Pagosa Springs is $270 \mathrm{ft}$ above McCabe Creek and this remnant is $330 \mathrm{ft}$ above the nearby San Juan River to the south. Distinct glacial spillways, which are depicted on map, cut Qob between Fourmile Ditch and Fourmile Creek in northeast part of quadrangle (about $0.5 \mathrm{mi}$ southeast of mouth of Quien Sabe Creek); here, Qob is 180-200 ft above Fourmile Creek. Unit thickness typically about $10 \mathrm{ft}$, but locally as much as $20 \mathrm{ft}$

Kame terrace (?) deposit (late middle Pleistocene) - Crudely stratified sand and gravel made of rounded volcanic clasts. This layered deposit is enigmatic because it is higher and isolated from other stratified gravel deposits and is unusually thick. Presumed source was former valley glacier in headwaters of Fourmile Creek where glacial cirques are preserved. If its origin is not glacial, it may be a remnant of an old terrace or pediment gravel deposit. Mapped only in one location (NE1/4, SW1/4, sec. 10, T. $36 \mathrm{~N}$., R. 2 W.) at 8,240-8,320 ft elevation. This deposit of presumed glaciofluvial origin is about $120 \mathrm{ft}$ above nearby Bull Lake outwash (Qob). Thickness at least $80 \mathrm{ft}$ based on geomorphology; base covered

Diamicton (Holocene to late middle Pleistocene?) - Brownish-gray and very dark grayish-brown, moderately compact, unsorted, nonbedded, clay, silt, sand and gravel that is significantly modified by slope processes, mostly landsliding and slumping. Poorly exposed and mapped only in northeast corner of quadrangle where unit primarily 
mantles hummocky, moderately steep, southwest-facing valley flank of Fourmile Creek. Gravel may be glacial-glaciofluvial in origin (outwash and [or] till), in part based on the presence of glacial cirques in the headwaters of Fourmile Creek. If not glacial or glaciofluvial in origin, gravel may be lag derived from former, old pediment gravels. Although the gravel's position in landscape is significantly modified by younger landslides and slumps, its overall relatively high position suggests a Bull Lake or older age (late middle Pleistocene?). Hummocky topography characterizes landslides and slumps within unit and implies a younger, Holocene to late Pleistocene age for these features. Unit mapped as diamicton and assigned a broad age range to reflect that it includes remnants of old gravel deposits mixed with and modified by younger landslides, slumps, and colluvium. Gravel includes granules, pebbles, cobbles, and boulders; most are rounded, but some are subangular. Gravel clasts are mainly composed of volcanic tuff, but some sandstone and sparse coarse-grained granite clasts are also present. Thickness unknown, but in general relatively thin, perhaps mostly $<25 \mathrm{ft}$ thick

\section{MASS WASTING DEPOSITS}

Qt

Qc

Qls

Qdf
Talus (Holocene) - Cobble- and boulder-size angular blocks of Dakota Sandstone below cliffs and fault scarps; mapped only along the Stinking Springs fault; thickness 5-10 ft

Colluvium (Holocene) - Gravelly sand, silt, clay, and dark yellow brown clay chips. Includes pebble-, cobble-, and boulder-size rock fragments of Dakota Sandstone (Kd) derived from upslope and transported downward mainly by creep. Locally contains unreworked deposits of terrace or pediment gravel; commonly overlies yellowish-brown clayey residuum on shale; contains slump blocks and thin beds of possible mudflow deposits in north part of map area. Widespread on shale in northern part of map area. Mostly present on lower hillslopes; colluvium $\leq 3 \mathrm{ft}$ thick was not mapped. On dip slopes of Dakota Sandstone, the unit locally includes jumbled, angular fragments of broken sandstone as large as $2 \mathrm{ft}$ across in a strong brown matrix of silt and fine sand. Thicknesses $2-6 \mathrm{ft}$

Landslide deposit (Holocene and late Pleistocene) - Sandstone and shale fragments, mixed with sand and clay. Forms chaotic hummocky landform on steep hillslopes mainly in north part of quadrangle; water seeps from deposit in wet season, many show signs of downhill creep; thickness unknown, possibly $6-15 \mathrm{ft}$

Debris-flow deposit (late to late middle Pleistocene?) - Unsorted volcanic gravel, sand, silt, and clay that caps isolated, relatively steeply southward sloping even surfaces that are not gullied and aligned more or less north-to-south. Thin loess scattered on surface. Poorly exposed and bedding, if present, was not observed. Gravel consists of weathered and rounded large cobbles and small boulders (pock marked, largest boulder 30 in.) of pale-red, biotite-rich porphyry and dark brown and greenish volcanic porphyry clasts. Mapped as several small, scattered, deposits in northwest part of map area; the unusual "J" shaped deposit in south half of sec. 28 , T. 36 N., R. 2 W., suggests that it is a remnant of a formerly more extensive deposit; thickness $6-10 \mathrm{ft}$

\section{BEDROCK UNITS}

The bedrock units listed below consist of sedimentary rocks that are exposed at the surface in the map area (described directly below) and older, subsurface rock units (sedimentary, igneous, and metamorphic rocks) that are not exposed at the surface. The subsurface rock units are known from drill holes that penetrate these units; they are described at the end of this section, are only shown in the cross sections, and they are also briefly discussed in the "cross sections and subsurface information" section of this report.

\section{SEDIMENTARY ROCK}

Names of stages and formations and members follow Dane and others (1966) and Leckie and others (1997). We did not identify biostratigraphic zones as did other workers for some of these units elsewhere (for example, Cobban and others, 2006), who used index fossil ammonites and clams. 
Lewis Shale (Upper Cretaceous, Campanian)—Dark olive gray to dark grayish brown fissile shale, firm to soft, interbeds of very fine sandy carbonaceous siltstone and silty, very fine sandstone, slightly clayey. Unit poorly exposed. Observed one horizon of thick, discoid concretions 2-3 ft diameter cut by veins of calcite spar; very hard calcareous septarian concretions grayish brown, weathers pale yellow; apparently several horizons of concretions; poor exposures preclude reliable count; extensive slumping in this shale. An unknown thickness of the upper part is eroded. Eroded thickness approximately $250 \mathrm{ft}$

KImv Lewis Shale and Mesaverde Group, undifferentiated (Upper Cretaceous, Campanian) - In the map area, the boundary between these two undifferentiated units (Lewis Shale and Mesaverde Group) is not recognizable, owing to its gradational and interfingering character, thick colluvial and vegetation cover, and apparent low dip of bedding. In part, this undifferentiated unit represents a zone of transition between marine shale of the Lewis and nonmarine sandy units of the Mesaverde Group. Unit underlies an approximately 4-mile long line of northeast-trending hills northeast of McCabe Creek. The first distinct beds near the base, observed in road cuts, are thin $0.8-2.3$ in., brownish yellow, very fine grained sandstone beds; sandstone contains heavy minerals and lithic grains and displays planar bedding and oscillation ripples. Sandstone beds are as much as $0.4-5 \mathrm{in}$. thick and have interbeds of grayish brown shale that are $0.4-0.8$ in. thick. Upper part of unit is mostly shale and very few sandstone beds. Sandstone is pale yellow, light gray silty very fine sand. Mapped thickness ranges from approximately 200 to about $600 \mathrm{ft}$

Kmv Mesaverde Group, undivided (Upper Cretaceous, Campanian)-Members named in the type area (Mesa Verde National Park) are indistinguishable in the Pagosa Springs map area. Unit is mostly shale that is dusky yellow, grayish brown, or olive gray. On slopes, unit mantled by weathered residuum from which thin (1-3 in. thick) sandstone interbeds protrude and break off to form "float" of thin, flaggy sandstone pieces. Abundant very thin, coarse-grained siltstone beds, yellowish-brown, slightly sandy and clayey and strongly calcareous, sparsely micaceous; common trails, burrows, prod marks on bedding surfaces; planar beds break to chips and very fine plates $0.1-0.2$ in. thick and as much as 16 in. across; Sandstone interbeds and laminae are pale yellow silty, very fine subangular quartz and lithic grains (sublitharenite); thickest sandstone bed seen was $5 \mathrm{ft}$. Some sandstone beds are calcareous and contain sparse subrounded quartz sand grains; sandstone planar beds uniformly $0.8-2$ in. thick, finely burrowed, sparse fragments of Inoceramus fossil clams; matrix typically is $30-40$ percent of sandstone beds and is hydrous iron oxide and iron oxide-clay minerals. Unit contains minor organic shale, traces of heavy minerals, a few calcareous light-yellowish-brown concretions (as much as $3 \mathrm{ft}$ across), zones of thinly laminated siltstone, and some low amplitude (0.8-1.5 in.) current and oscillation ripples of 4 in. wave length on bedding planes. Base of unit interbedded shale and sandstone grading to Mancos Shale below. Thickness in Pagosa Springs quadrangle as much as $260 \mathrm{ft}$. Molenaar and others (2002) report that the unit is thicker west of the quadrangle

Mancos Shale (Upper Cretaceous) —Eight members of the Mancos Shale, consisting of four formal and four informal members, were identified in the map area. The upper two members, the Cortez and Smoky Hill members (informal after Leckie and others, 1997), were not mapped separately and instead were combined and mapped together as the undifferentiated upper part of the Mancos Shale. The other six members were mapped separately. As such, the Mancos Shale comprises seven map units that are shown on the geologic map and described below

Kmu Mancos Shale, undifferentiated upper part (Upper Cretaceous, lower Campanian to middle Coniacian)—Equivalent to, from top to bottom, Cortez and Smoky Hill members of Mancos Shale (Leckie and others, 1997). Dark gray and grayish brown fissile shale weathers white on flat surfaces; silty; probably accumulated in relatively deep marine water. Lower part of unit (Smoky Hill member) is chalky shale and clayey chalk with probable coccoliths (Neugebauer, 1975) and associated nannofossils. Uppermost shale in this unit grades upwards into thin-bedded, olive brown calcareous very fine, 
somewhat lithic sandstone (sublitharenite). Shale contains innumerable white flecks visible with magnifier, and shiny, transparent spheres (0.0025 in.) singly or in clusters (foraminifera?); very small pyrite crystals; sparse bluish white, phosphatic bone pieces $0.04-0.08$ in. long and small ( $0.2-0.8$ in.) oyster type shells attached to fragments of prismatic clam shells $0.1-0.8$ in. thick, grooved rectangular-shaped shell fragments, a few 2-3 in. long. Thin beds of oyster coquina are present. Few beds containing small fossil fringed oysters (Lopha lugubris), fossil selachian fish scales (cartilaginous fishes including sharks and rays) light bluish-white and fine sand size; ptychodus skate teeth believed evolved for crushing clam and oyster shells. Ptychodus teeth collected near McCabe Creek, 3 mi north of Pagosa Springs. Thickness 800-950 ft

$\mathrm{Kmf}$

Fort Hays Limestone Member (Upper Cretaceous, lower Coniacian)—Interbedded chalky limestone and chalky shale. Very finely crystalline and microcrystalline chalky limestone, broken surface is medium olive gray, weathers light olive gray, light gray, and yellowish-gray; limestone contains foraminifera, common to abundant calcite prisms derived from disintegrated shells of inoceramid clams (pelecypods). Unit contains thin beds of bentonite (devitrified volcanic ash); whole and fragmentary Inoceramus fossils (cf. Mytiloides?), some are auriculate (have an ear-like extension at the beak of shell). In outcrop, unit typically has thin limestone ledges, each ranging in thickness 8-16 in., interbedded with calcareous gray mudstone and shale. Outcrop covered in places with brownish-gray oxidized (weathered) silty, clayey, and sandy residual soil of Mancos Shale and weathered, colluvial volcanic gravel clasts. Outcrop commonly sloughs angular, flat limestone fragments $0.3-3$ in. on a brown shale hillslope; in stream cutbanks and road cuts, unit crops out as distinct alternating ledges and clayey layers. Locally shown on map as colored line where this distinctive and continuous unit is too thin to otherwise portray at the map scale. Thickness of unit 14-16 ft

Kmmv Montezuma Valley member (informal name after Leckie and others, 1997; Upper Cretaceous, upper Turonian)—Medium olive gray silty to slightly sandy, calcareous shale. Contains a few bentonite layers and septarian concretions some of which contain inoceramid clam shells. Unit is $70-150 \mathrm{ft}$ thick

Kmj Juana Lopez Member (Rankin, 1944; Upper Cretaceous, upper Turonian)— Predominantly very dark gray mudstone, shale, and brown-weathering interbeds of calcarenite (limestone composed of calcite grains and crystals). Some freshly broken calcarenite has petroliferous odor. Outcrops form low cuestas of dark gray (light-gray weathering) calcareous clayey shale and mudstone with light gray layers of bentonitic clay and gray (unweathered) and dark yellowish-brown, olive, and brown (all weathered), platy calcarenite interbeds that are $0.5-8$ in. thick, and rarely as thick as 15 in.; limestone concretions, as much as $2.5 \mathrm{ft}$ in diameter (some are septarian). Small, platey fragments of calcarenite slough off exposed beds, veneering shale slopes below. The unit contains abundant Lopha lugubris (ribbed oyster shells) that are $1 \mathrm{in}$. or less in diameter and commonly mixed with other shell fragments in concretions. The Juana Lopez occurs in the San Juan and the Raton Basins, and in several Great Plains states.

Calcarenite consists of sand-size calcite grains that are rounded or "prism-like," about $0.5 \mathrm{~mm}$ long, and commonly tapered at one end. They are abraded calcite prisms derived from the ostracum layer of shells of Inoceramid pelecypods (clams); the calcarenite contains thin skeletal grainstone beds and lenses containing planktonic foraminiferal tests, fish scales, teeth, and vertebrae (fish? bone). Lenses and thin wavy beds, wavy parallel laminations, parallel orientation of long axes of prisms, laminated crossbedding, and flaser bedding (separate lenses) of calcarenite intercalated with shale indicate that bottom currents swept the calcite prisms into ripples on a muddy seafloor.

Locally shown on map as colored line where this distinctive and continuous unit is too thin to otherwise portray at the map scale. Thickness of member is $20-30 \mathrm{ft}$ in Pagosa Springs quadrangle, but Dane and others (1966) report thicknesses of 90-135 ft in the eastern San Juan Basin near Ventana, New Mexico

$\mathrm{Kmc}$

Carlile shale member (informal following Dane, 1948; Upper Cretaceous, middle Turonian) - Very dark gray, calcarenitic, silty, fissile shale. Covered in south-central part of map area by residuum mixed with gray silt, clayey sheetwash, and loess; this 
surface material typically is about $4-5 \mathrm{ft}$ thick and overlies weathered, plastic shales of this member on a sharp contact. Unit veneered in places by angular limestone fragments, 6-24 in. diameter. A layer of concretions (about $3 \mathrm{ft}$ diameter) exists $20-30 \mathrm{ft}$ below lowest calcarenite bed of the overlying Juana Lopez Member. Thickness of unit $130-233 \mathrm{ft}$

$\mathrm{Kmb} \quad$ Bridge Creek Limestone Member (Upper Cretaceous, middle to lower Turonian) Gray weathers very pale brown. Rhythmic alternating, planar, thin (1.5-12 in.) beds of silty, calcareous gray shale and chalky limestone; includes five to six moderately hard limestone beds $12-20$ in. thick that protrude from outcrop, separated by calcareous nonfissile shale (marl); vertical joints facilitate breaking limestone to chips and pencil-shaped fragments. Limestone contains few carbonaceous impressions of Inoceramus clams. An inocermid collected from the upper part of this unit was identified by W.A. Cobban (USGS, deceased) as Mytiloides mytiloides. Unit crops out somewhat subtly on gentle hillslopes, but distinctly in stream banks and roadcuts. Thickness $17-25 \mathrm{ft}$

Graneros Shale Member (Upper Cretaceous, upper Cenomanian)—Noncalcareous, dark gray, fissile shale, silty in places and contains a thin sandstone bed in places, especially in the lower 10-30 ft. Contains few altered volcanic ashfall (bentonitic clay) layers; concretions of subspherical shape (some mushroom-like), 3-4 ft across, occur in layers at $20-65 \mathrm{ft}$ above base of unit; in places, unit veneered by $2-3 \mathrm{ft}$ of silty clay loess, sheetwash, thin $(<1 \mathrm{ft}$ thick) sandstone lag gravel, and residuum. Thickness $100-170 \mathrm{ft}$.

A Tertiary (Neogene?) small mafic (lamprophyre or diabase?) dike is exposed in outcrop (NW 1/4 sec 14, T. 35 N., R. 2 W. [1.4 mi; 2.2 km northwest of the Pagosa hot springs]). Dike is about $3 \mathrm{ft}$ wide. May be an outlier of the north-south oriented dike field associated with the Archuleta anticlinorium, or related to the Jackson Mountain intrusive stock northeast of the map area silty quartz sandstone composed mostly of subrounded grains (few well rounded); typically yellowish-gray, grayish-orange, light gray and dark gray; weathers dark yellowish-orange. Sandstone is mostly silica-cemented and hard (forms cliffs), but weathered zones are easily broken and fragmented. Includes 5-10 percent white, opaque small, elongated prisms of feldspar, altered to kaolinite(?), trace of muscovite and heavy minerals or lithic silt, and sparse, partial casts of ribbed shells (clams?); flinty (milky opaque chert cement) texture in places; many bedding planes show abundant burrows with lens-shaped cross sections; includes medium-scale (1-2 ft) interbeds of cross-bedded, fine-grained sand (about 95 percent quartz) and some herringbone crossbedding; unit chiefly thin to thick bedded and well sorted; locally has euhedral quartz overgrowths on sand grains. The Dakota contains few thin beds of silt and sandy shale and thin, wavy laminae and beds of lignite or dark gray bioturbated carbonaceous clay and fine-grained quartz sandstone that weathers like shale and contains disseminated, fine particles of coalified vegetation. The base of Dakota rests on a paraconformity on the Morrison Formation (Aubrey, 1992). Covering the surface of the Dakota, about 1.5-2 mi (1.5-3 km) west of town (sec. 22, T. 35 N., R. 2 W.), is angular lag sandstone gravel; this is atypical in the map area. On dip slopes of 8 percent grade or less near faults (upthrown block), the Dakota is covered by 1-3 ft of dark brown and reddish-brown loamy, very silty fine sand residuum and loess, and small blocks of sandstone; on slopes more than about 8 percent grade, it is bare rock. In Martinez Canyon area (southwest corner of map) total thickness of unit is about $200-230 \mathrm{ft}$, and within canyon, $48 \mathrm{ft}$ of unit is well exposed in a cliff face; a partial exposure about $55 \mathrm{ft}$ thick was observed in Piedra Canyon northwest of map area; total thickness reported in drill holes in town of Pagosa Springs was as much as $200 \mathrm{ft}$ (Galloway, 1980), and ranges between 150 and $250 \mathrm{ft}$ in other drill holes in and nearby map area out in a poorly exposed 159-ft-thick partial section of the Morrison Formation below a sharp contact (unconformity) with the overlying Dakota Sandstone. The Morrison 
sandstones are torrentially cross-bedded in places ( $20^{\circ}$ dipping foreset beds) and are separated by presumed claystone (covered). The sandstone is soft, sugary texture in places, and contains medium-grained quartz sand that is well rounded, frosted, and moderately well sorted. Thin, planar sandstone beds weather to slabs. No fossils were observed. In most places in Colorado, the Morrison also displays distinctive beds of pale varicolored claystone and minor nodular limestone; the partial and poorly exposed Morrison sequence in Martinez Canyon may contain such interbeds, but none were observed. In the map area and San Juan Basin, the Morrison is truncated at the top by a regional unconformity at the base of the overlying Dakota Sandstone (Aubrey, 1992). Mudstones of the Morrison have yielded well preserved entire dinosaur skeletons, for example in Garden Park, Colorado, and Dinosaur National Monument, Utah. Galloway (1980) reported $681 \mathrm{ft}$ of Morrison Formation (undifferentiated) in a deep geothermal well (CGS Test Well, P-1) in Pagosa Springs; other wells in and nearby map area indicate thicknesses of as much as $750 \mathrm{ft}$, and as little as $280 \mathrm{ft}$. In the northeastern part of map area, the Morrison Formation unconformably overlies Precambrian granite and gneiss in the subsurface (H.R Macht no.1 well; cross section $B-B^{\prime}$ ); in other wells, it overlies the Wanakah Formation in the subsurface (see cross sections $A-A^{\prime}$ and $C-C^{\prime}$ ). Thickness of upper part of Morrison Formation in Martinez Canyon is 110-120 ft, base is covered

Wanakah Formation (upper Middle Jurassic)—Present at least locally in subsurface and only shown in cross sections. Limestone and anhydrite $\left(\mathrm{CaSO}_{4}\right)$. Where encountered in drill holes, underlies Morrison Formation and overlies Entrada Sandstone. Unit is correlative to Todilto Formation in northern New Mexico (Anderson and Lucas, 1992). Thickness in drill hole in southeast part of map is $96 \mathrm{ft}$ (CGS Test Well, P1; see $C^{-} C^{\prime}$ ); thickness in drill hole just west of map area is $91 \mathrm{ft}$ (Strat no. 1 well; see $A-A^{\prime}$ ); absent in drill hole in northeast part of map (H.R Macht no.1 well; see $B-B^{\prime}$ ). Apparently, unit was either not deposited or was eroded prior to deposition of the Morrison Formation $(\mathrm{Jm})$ in the northeastern part of the map area where the H.R Macht no. 1 well is located only shown in cross sections. Sandstone, quartzose and slightly feldspathic, fine- to coarse-grained, poorly sorted, some frosted grains. Where encountered in drill holes, underlies Wanakah Formation and overlies crystalline, Precambrian rocks. Thickness in drill hole in southeast part of map is $159 \mathrm{ft}$ (CGS Test Well, $\mathrm{P}-1$; see $\left.C-C^{\prime}\right)$; thickness in drill hole just west of map area is $91 \mathrm{ft}$ (Strat no.1 well; see $A-A^{\prime}$ ); absent in drill hole in northeast part of map area (H.R Macht no. 1 well; see $B-B^{\prime}$ ). Unit is a minimum of about $230 \mathrm{ft}$ thick where it is exposed in Piedra Canyon west of the map area. Like the Wanakah (Jw), this formation apparently was either not deposited or was eroded prior to deposition of the Morrison Formation (Jm) in the northeastern part of the map where the H.R Macht no.1 well is located

\section{IGNEOUS AND METAMORPHIC ROCK}

Gneiss and granite (Precambrian, Proterozoic) — Present at least locally in subsurface and only shown in cross sections. Contains pegmatite, migmatite, and biotite schist (Galloway, 1980). Underlies Morrison Formation in drill hole in northeast part of map area (H.R. Macht no. 1 well; see $B-B^{\prime}$ ) and underlies Entrada Sandstone in drill hole in southeast part of map area (CGS Test Well, P1; see $C-C^{\prime}$ ) and in drill hole west of map area (Strat no. 1 well; see $A-A^{\prime}$ ). These three wells all bottomed in these Precambrian rocks; $112 \mathrm{ft}$ of this unit penetrated in CGS Test Well, $\mathrm{P}-1 ; 6 \mathrm{ft}$ penetrated in Strat no. 1 well, and only $2 \mathrm{ft}$ penetrated in H.R Macht no. 1 well; true thickness unknown, likely many miles thick 


\section{References Cited}

Anderson, O.J., and Lucas, S.G., 1992, The middle Jurassic Summerville Formation, northern New Mexico: New Mexico Geology, v. 14, no. 4, p. 79-92.

Atwood, W.W., and Mather, K.F., 1932, Physiography and Quaternary geology of the San Juan Mountains, Colorado: U.S. Geological Survey Professional Paper 166, 176 p.

Aubrey, W.M., 1992, New interpretations of the stratigraphy and sedimentology of uppermost Jurassic to lowermost Upper Cretaceous strata in the San Juan Basin of northwestern New Mexico: U.S. Geological Survey Bulletin 1808J, p. J1-J17. [Also available at https://pubs.er.usgs.gov/ publication/b1808JK.]

Bachmann, O., Dungan, M.A., and Lipman, P.W., 2000, Voluminous lava-like precursor to a major ash-flow tuffLow-column eruption of the Pagosa Peak Dacite, San Juan volcanic field, Colorado: Journal of Volcanology and Geothermal Research, v. 98, no. 1-4, p. 153-171.

Baltz, E.H., 1967, Stratigraphy and regional tectonic implications of part of the Upper Cretaceous and Tertiary rocks, east-central San Juan Basin, New Mexico: U.S. Geological Survey Professional Paper 552, 101 p.

Barron, E.J., 1983, A warm, equable Cretaceous, the nature of the problem: Earth Science Review, v. 19, no. 4, p. 305-338.

Benson, L., Madole R., Landis, G., and Gosse, J., 2005, New data for late Pleistocene Pinedale alpine glaciation from southwestern, Colorado: Quaternary Science Reviews, v. 24 , no. 1-2, p. 49-65.

Bilodeau, W.L., and Lindberg, F.A., 1983, Early Cretaceous tectonics and sedimentation in southern Arizona, southwestern New Mexico, and northern Sonora, Mexico in Reynolds, M.W., and Dolly E.D., eds., Mesozoic paleogeography of the west-central United States: Society of Economic Paleontologists and Mineralogists, Rocky Mountain Paleogeography Symposium 2, p. 173-188.

Bird, P., 1988, Kinematic history of the Laramide orogeny in latitudes $35^{\circ}-49^{\circ} \mathrm{N}$, western United States: Tectonics, v. 17, no. 5 , p. $780-801$.

Blackwelder, E., 1915, Post-Cretaceous history of the mountains of central Wyoming, Part III: Journal of Geology, v. 23 , no. 2 , p. 307-340.

Blakey, R.C., and Ranney, W., 2008, Ancient landscapes of the Colorado Plateau: Grand Canyon Association, 156 p.

Carroll, C.J., Gonzales, D.A., Gianniny, G.L, Houck, K.J., Watterson, N.A., Skyles, E.M., and Stetson-Lee, T., 2011, Geologic map and coal bed stratigraphy of the Fruitland Formation in western Archuleta County, Colorado: Colorado Geological Survey Map Series 49, scale 1:24,000, pamphlet $42 \mathrm{p}$.
Cather, S.M., 2003, Polyphase Laramide tectonism and sedimentation in the San Juan Basin, New Mexico, in Lucas, S.G., Semken, S.C., Berglof, W., and Ulmer-Scholler, D., eds., Geology of the Zuni Plateau: New Mexico Geological Society Fall Field Conference Guidebook 54, p. 119-132.

Cobban, W.A., and Reeside, J.B., Jr., 1952, Correlation of the Cretaceous formations of the Western Interior of the United States: Geological Society of America Bulletin, v. 63, no. 10, p. 1011-1043.

Cobban, W.A., Walaszezyk, I., Obradovich, J.D., and McKinney, K.C., 2006, A USGS zonal table for the Upper Cretaceous middle Cenomanian-Maastrichtian of the Western Interior of the United States based on ammonites, inoceramids, and radiometric ages: U.S. Geological Survey Open-File Report 2006-1250, 45 p.

Cohen, K.M., Finney, S.C., Gibbard, P.L. and Fan, J.X., 2013, International chronostratigraphic chart: International Commission on Stratigraphy, Episodes, 36, p. 199-204, accessed February 6, 2017, at http://www.stratigraphy.org/index.php/ ics-chart-timescale. [Updated in 2017.]

Condie, K.C., 1992, Proterozoic terranes and continental accretion in southwestern North America, in Condie, K.C., ed., Proterozoic crustal evolution: Developments in Precambrian geology 10, p. 447-471.

Cope, E.D., 1885, The relations of the Puerco and Laramie deposits: American Naturalist, v. 19, p. 985-986.

Dane, C.H., 1948, Geology and oil possibilities of the eastern side of the San Juan Basin, Rio Arriba County, New Mexico: U.S. Geological Survey Oil and Gas Investigations Map OM-78, scale 1:63,360. [Reprinted in 1957.]

Dane, C.H., Cobban, W.A., and Kauffman, E.G., 1966, Stratigraphy and regional relationships of a reference section for the Juana Lopez Member, Mancos Shale in the San Juan Basin, New Mexico: U.S. Geological Survey Bulletin 1224-H, 15 p.

Dickinson, W.R., and Snyder, W.S., 1979, Geometry of subducted slabs related to the San Andreas transform: Journal of Geology, v. 87, no. 6, p. 609-627.

Dott, R.H., Jr., 1979, Paleolatitude and paleoclimate: Wisconsin Academy of Sciences, v. 67, p. 4-13.

Duncan, R.A., and Richards, M.A., 1991, Hotspots, mantle plumes, flood basalts, and true polar wander: Reviews in Geophysics, v. 29, no. 1, p. 31-50.

Dunn, D.E., 1964, Evolution of the Chama Basin and Archuleta anticlinorium, eastern Archuleta County, Colorado: University of Texas, Austin, Ph.D. dissertation, 228 p.

Eaton, G., 2008, Epeirogeny in the Southern Rocky Mountains region-Evidence and origin: Geosphere, v. 4, no. 5, p. $764-784$. 
Epis, R.C., and Chapin, C.E., 1975, Geomorphic and tectonic implications of the post-Laramide, late Eocene erosion surface in the southern Rocky Mountains: Geological Society of America Memoir 144, p. 45-74.

Fassett, J.E., 1974, Cretaceous and Tertiary rocks of the eastern San Juan Basin, New Mexico and Colorado, in Siemers, C.T., Woodward, L.A., and Callender, J.F., eds., Ghost Ranch: New Mexico Geological Society Fall Field Conference Guidebook 25, p. 225-230.

Fullerton, D.S., Colton, R.B., and Bush, C.A., 2004, Limits of mountain and continental glaciations in northern Montana and north-western North Dakota, U.S.A. in Rose, J., ed., Quaternary glaciations-Extent and chronology, part IINorth America: Developments in Quaternary Sciences, p. $131-150$.

Galloway, M.J., 1980, Hydrogeologic and geothermal investigation of Pagosa Springs, Colorado: Colorado Geological Survey report, U.S. Department of Energy contract DE-AS07-77-28365-5, 80 p.

Gile, L.H., Peterson, F.F., and Grossman, R.B., 1966, Morphological and genetic sequences of carbonate accumulation in desert soils: Soil Science, v. 101, no. 5, p. 347-360.

Gillette, D.D., and Thomas, D., 1985, Dinosaur tracks in the Dakota Formation (Aptian-Albian) at Clayton Lake State Park, Union County, New Mexico: New Mexico Geological Society Guidebook 36, p. 283-288.

Gonzales, D.A., 2014, New U-Pb zircon and ${ }^{40} \mathrm{Ar} /{ }^{39} \mathrm{Ar}$ age constraints on the late Mesozoic to Cenozoic plutonic record in the western San Juan Mountains: Rocky Mountain Association of Geologists, The Mountain Geologist, v. 52, no. 2 , p. 5-42.

Hail, W.J., Jr., 1971, Geologic reconnaissance map of the Chris Mountain and Pagosa Springs quadrangles, Hinsdale and Archuleta Counties, Colorado: U.S. Geological Survey Open-File Report 71-142, scale 1:48,000.

Hall, R.D., and Michaud, D., 1988, The use of hornblende etching, clast weathering, and soils to date alpine glacial and periglacial deposits - A study from southwestern Montana: Geological Society of America Bulletin, v. 100, no. 3, p. $458-467$.

Haq, B.U., Hardenbol, J., and Vail, P.R., 1987, Chronology of fluctuating sea levels since the Triassic (250 million years ago to present): Science, v. 235, no. 4793, p. 1156-1167.

Karlstrom, K.E., and Bowring, S., 1988, Early Proterozoic assembly of tectonostratigraphic terranes in southwestern North America: Journal of Geology, v. 96, no. 5, p. 561-576.
King, L.R., Foster, J.R., and Scheetz, R.D., 2006, New pterosaur specimens from the Morrison Formation and a summary of the Late Jurassic pterosaur record of the Rocky Mountain region: Bulletin of the New Mexico Museum of Natural History and Science, v. 36, p. 109-113.

Kowallis, B.J., Christiansen, E.H., Deino, A.L., Peterson, F., Turner, C.E., Kunk, M.J., and Obradovich, J.D., 1998, The age of the Morrison Formation: Modern Geology, v. 22, p. $235-260$.

Leckie, R.M, Kirkland, J.I., and Elder, W.P., 1997, Stratigraphic framework and a principal reference section of the Mancos Shale (Upper Cretaceous), Mesa Verde, Colorado in Anderson, O.J., Kues, B.S., and Lucas S.G., eds., Mesozoic geology and paleontology of the Four Corners area: New Mexico Geological Society, Fall field conference guidebook 48, p. $163-189$.

Leonard, E.M., Laabs, B.J., Kroner, R.K., Plummer, M.A., Brugger, K.A., Refsnider, K.A., Spiess, V.M., and Caffee, M.W., 2017, Late Pleistocene glaciation and deglaciation in the Crestone Peaks area, Colorado Sangre de Cristo Range-Chronology and paleoclimate: Quaternary Science Reviews, v. 158, p. 127-144.

Lipman, P.W., 2006, Geologic map of the central San Juan caldera cluster, southwestern Colorado: U.S. Geological Survey Geologic Investigations Series I-2799, scale 1:50,000, pamphlet $34 \mathrm{p}$.

Liu, L., Gurnis, M., Seton, M., Saleeby, J.B., Muller, R.D., and Jackson, J.M., 2010, The role of oceanic plateau subduction in the Laramide orogeny: Nature Geoscience, v. 3, no. 5, p. 353-357.

Livaccari, R.F., Burke, K., Sengor, A.M.C., 1981, Was the Laramide orogeny related to subduction of an oceanic plateau?: Nature, v. 289, p. 276-278.

McIntosh, W.C., and Chapin, C.E., 2004, Geochronology of the central Colorado volcanic field: New Mexico Bureau of Geology and Mineral Resources Bulletin 160, p. 205-237.

McMillan, M.E., Angevine, C.L., and Heller, P.L., 2002, Post-depositional tilt of the Miocene-Pliocene Ogallala Group on the western Plains - Evidence of late Cenozoic uplift of the Rocky Mountains: Geology, v. 30, p. 62-66.

McMillan, M.E., Heller, P.L., and Wing, S.L., 2006, History and causes of post-Laramide relief in the Rocky Mountain orogenic plateau: Geological Society of America Bulletin, v. 118 , no. $3 / 4$, p. $393-405$.

McQuarrie, N., and Chase, C.G., 2000, Raising the Colorado Plateau: Geology, v. 28, no. 1, p. 91-94. 
Miller, K.G., Kominz, M.A., Browning, J.V., Wright, J.D., Mountain, G.S., Katz, M.E., Sugarman, P.J., Cramer, B.S., Christie-Blick, N., and Picar, S.T., 2005, The Phanerozoic record of global sea-level change: Science, v. 310, no. 5752, p. 1293-1298.

Molenaar, C.M., Cobban, W.A., Merewether, C.I., Pillmore, C.L., Wolfe, D.G., and Holbrock, J.M., 2002, Regional stratigraphic cross sections of Cretaceous rocks from east-central Arizona to the Oklahoma panhandle: U.S. Geological Survey Miscellaneous Field Studies Map MF-2382, scale 1:760,320 and 1:792,000, 3 plates.

Moore, D.W., 2010, Geologic map of the Edwards aquifer and related rocks in northeastern Kinney and southernmost Edwards Counties, south-central Texas: U.S. Geological Survey Scientific Investigations Map 3105, pamphlet 18 p., scale 1:50,000. [Also available at https://pubs.usgs.gov/ $\operatorname{sim} / 3105$.]

Moore, D.W., Lidke, D.J., and VanSistine, D.P., 2018, Data release for the geologic map of the Pagosa Springs 7.5' quadrangle, Archuleta County, Colorado: U.S. Geological Survey data release, https://doi.org/10.5066/P9WRSUI6.

Muehlberger, W.R., 1967, Geology of the Chama quadrangle, New Mexico: New Mexico Bureau of Mines and Mineral Resources, Bulletin 89, 122 p.

Neugebauer, J., 1975, Fossil-diagenese in der schreibkreideCoccolithen: Neus Jahrbuch Geologie Paläontologie, Monatshefte, p. 321-338.

Obradovich, J.D., 1993, A Cretaceous time scale, in Caldwell W.G.E., and Kauffman, E.G., eds., Evolution of the Western Interior Basin: Geological Association of Canada Special Paper 39, p. 379-396.

Pederson, J.L., Mackley, R.D., and Eddleman, J.L., 2002, Colorado Plateau uplift and erosion evaluated using GIS: GSA Today, v. 12, p. 4-10.

Peterson, F., 1988, Stratigraphy and nomenclature of Middle and Upper Jurassic rocks, western Colorado Plateau, Utah and Arizona, chap. B of Revisions to stratigraphic nomenclature of Jurassic and Cretaceous rocks of the Colorado Plateau: U.S. Geological Survey Bulletin 1633-A-C, p. 13-56.

Pierce, K.L., 2003, Pleistocene glaciation of the Rocky Mountains: Developments in Quaternary Science, v. 1, p. 63-76.

Pipiringos, G.N., and O’Sulllivan, R.B., 1978, Principal unconformities in Triassic and Jurassic rocks, Western Interior United States - A preliminary survey: U.S. Geological Survey Professional Paper 1035-A, 29 p.

Rankin, C.H., 1944, Stratigraphy of the Colorado GroupUpper Cretaceous, in northern New Mexico: New Mexico Bureau of Mines Mineral Resources Bulletin 20, 27 p.
Richmond, G.M., 1965, Glaciation of the Rocky Mountains, in Wright, H.E., Jr., and Frey, D.G., eds., The Quaternary of the United States: Princeton, N.J., Princeton University Press, p. 217-230.

Schweinsberg, A.D., Briner, J.P., Shroba, R.R., Licciardi, J.M., Leonard, E.M., Brugger, K.A., and Russell, C.M., 2016, Pinedale glacial history of the upper Arkansas River Valley-New moraine chronologies, modeling results, and geologic mapping, in Keller, S.M., and Morgan, M.L., eds., Unfolding the geology of the west: Geological Society of America Field Guide 44, p. 335-353, accessed February 15, 2018, at https://doi.org/10.1130/2016.0044(14).

Scott, G.R., and Moore, D.W., 2007, Pliocene and Quaternary deposits in the northern part of the San Juan Basin in southwestern Colorado and northwestern New Mexico: U.S. Geological Survey Scientific Investigations Report 2007-5006, 13 p.

Scott, R.B., Harding, A.E., Hood, W.C., Cole, R.D., Livacarri, R.F., Johnson, J.B., Shroba, R.R., and Dickerson, R.P., 2001, Geologic map of Colorado National Monument and adjacent areas, Mesa County, Colorado: U.S. Geological Survey Geologic Investigations Series I-2740, pamphlet 37 p., scale 1:24,000.

Shackleton, N.J., Backman, J., Zimmerman, H., and Westberg-Smith, J., 1984, Oxygen isotope calibration of the onset of ice rafting and history of glaciation in the North American region: Nature, v. 307, p. 620-623.

Shaw, C.A., Heizler M.T., and Karlstrom, K.E., 2005, ${ }^{40} \mathrm{Ar} /{ }^{39} \mathrm{Ar}$ thermochronologic record of $1.45-1.35 \mathrm{Ga}$ intracontinental tectonism in the southern Rocky MountainsInterplay of conductive and advective heating with intracontinental deformation, in Karlstrom, K.E., and Keller, G.R., eds., The Rocky Mountain region-An evolving lithosphere: Washington D.C., American Geophysical Union, Geophysical monograph series, v. 154, p. 163-184.

Shroba, R.R., and Birkeland, P.W., 1983, Trends in late-Quaternary soil development in the Rocky Mountains and Sierra Nevada of the western United States, in Porter, S.C., ed., The Late Pleistocene, v. 1 of Wright, H.E., Jr., ed., Late Quaternary Environments of the United States: Minneapolis, Minn., University of Minnesota Press, p. $145-156$.

Skipp, G., and Aubrey, W.M., 1992, X-ray diffraction studies of the $<2-\mu \mathrm{m}$ fraction from the upper part of the Brushy Basin Member of the Upper Jurassic Morrison Formation and Lower Cretaceous Burro Canyon Formation in the Four Corners Area, Colorado: U.S. Geological Survey Bulletin 1808-K, p. K1-K11. 
Steven, T.A., Lipman, P.W., Hail, W.J., Jr., Barker, F., and Luedke, R.G., 1974, Geologic map of the Durango quadrangle, southwestern Colorado: U.S. Geological Survey Miscellaneous Investigation Series Map I-764, scale 1:250,000.

Steven, T.A., and Lipman, P.W., 1976, Calderas of the San Juan volcanic field, southwestern Colorado: U.S. Geological Survey Profession Paper 958, p. 1-35.

Taylor, B., 2006, The single largest oceanic plateau—Ontong Java-Manihiki-Hikurangi: Earth and Planetary Science Letters, v. 241, p. 372-380.

Turner, C.E., and Fishman, N.S., 1991, Jurassic Lake T'oo'dichi'-A large alkaline, saline lake, Morrison Formation, eastern Colorado Plateau: Geological Society of America Bulletin, v. 103/4, p. 538-558.

Turner, C.E., and Peterson, F., 2004, Reconstruction of the Upper Jurassic Morrison Formation extinct ecosystem-A synthesis: Sedimentary Geology, v. 167, p. 309-355.

Tweto, O., 1975, Laramide (Late Cretaceous-early Tertiary) orogeny in the Southern Rocky Mountains: Geological Society of America Memoir 144, 44 p.

U.S. Census Bureau, 2010, Census 2010: American FactFinder, accessed on August 3, 2010, at https://factfinder. census.gov/faces/nav/jsf/pages/community_facts.

$\mathrm{xhtml}$ ?src=bkmk.

U.S. Geological Survey, 1966, Age of basalt cap on Grand Mesa, in chapt. A of Geological Survey research 1966: U.S. Geological Survey Professional Paper 550, p. A81.

Walker, M.J.C., Berkelhammer, M., Björck, S., Cwynar, L.C., Fisher, D.A., Long, A.J., Lowe, J.J., Newnham, R.M., Rasmussen, S.O., and Weiss, H., 2012, Formal subdivision of the Holocene Series/Epoch-A discussion paper by a working group of INTIMATE (Integration of ice-core, marine and terrestrial records) and the Subcommission on Quaternary Stratigraphy (International Commission on Stratigraphy): Journal of Quaternary Science, v. 27, no. 7, p. 649-659.

Weimer, R.J., and Land, C.B., 1972, Field guide to Dakota Group (Cretaceous) stratigraphy, Golden-Morrison area, Colorado: The Mountain Geologist, v. 9, p. 241-267. 


\section{Glossary}

Anticlinorium Regional, elongated arch of sedimentary rock formed by compressive forces; includes smaller, second-order anticlines and synclines.

Ash-flow tuff Extrusive volcanic rock formed by violent eruptions and spread by a dense, ground-hugging cloud of extremely hot gas and rock particles, a so-called "fiery cloud."

B horizon A middle or lower zone of a soil, under the A horizon and above a $\mathrm{C}$ horizon or bedrock; in the map area, usually enriched with clay $(<0.002 \mathrm{~mm}$ diameter) and the lower part of older B horizons are also enriched with carbonate. Downward-seeping meteoric water carries clay and colloids, which accumulate in this layer whose texture, color, and coherence are distinctive. Oxidation of iron minerals in the $\mathrm{B}$ reddens it; centuries in age.

Calcarenite Limestone consisting of sand-size grains of calcium carbonate (calcite).

Coccolith Microscopic calcium carbonate plate (about 1 micron) of the phytoplankton spherical exoskeleton (one-celled marine plants) which is about 25 microns across. Seafloor ooze of the plates becomes chalky limestone.

Colluvium Surficial rock debris and soil moved downslope by gravity.

Diamicton Debris of uncertain origin; unbedded, unsorted (clay to boulders), unconsolidated material possibly deposited by a glacier or landsliding.

Epicontinental sea On the surface of a continent; a relatively shallow inland sea; differs from deep oceans, such as the Atlantic.

Epeirogeny Uplift of a region of continental crust.

Fluvial terrace deposit A tabular body of gravel that covers a terrace (bench or tread); usually bound by a scarp; an erosional remnant of river channel gravel of rounded resistant stones.

Foraminifera Single-celled marine organism (ameboid protist) that secretes a small $(<1-4 \mathrm{~mm})$ shell of calcium carbonate extracted from seawater.
Ga (Giga annum) billion years.

Grainstone A rock having depositional texture that lacks mud and is grain supported.

Index fossil A distinctive, relatively short-lived, widespread fossil; used to correlate sedimentary rock units of similar age.

ka kilo-annum (thousand years).

Laramide orogeny Mountain building period in western North America, about 70 to 40 million years ago, when the modern Rocky Mountains formed; first recognized in the Laramie Mountains, Wyoming.

Ma Mega-annum, million years ago.

Mass wasting Gravity-driven movement of rock and soil down slopes.

Micritic (microscopically crystalline) A limestone texture having distinct tiny crystals viewed with microscope.

Outwash Gravel sand and finer detritus deposited by glacial meltwater.

Pediment deposit Gently sloping thin cover of detritus on bedrock. In northern part of quadrangle, isolated, south-sloping pediment-deposit remnants are located on foothills of mountains to north.

Pleistocene Epoch Young geologic time (<2.6 Ma) informally divided into early, middle, and late for purposes of this map; part of the Quaternary Period.

Porphyry (adjective: porphyritic) Igneous rock made of large mineral crystals "floating" in a finely crystalline matrix.

Residuum In-place mineral particles and soil formed by rock weathering; not transported.

Septarian concretion Large, nearly oblate spheroid of clayey limestone made of irregular blocks separated by calcite-filled cracks. Occur in shale and may contain fossil mollusks.

Subduction Sinking of a tectonic plate, usually dense oceanic crust, into the mantle below another plate as the two collide (converge).

Terrace Flat or gently inclined surface, generally long and narrow, bound by descending steep slope at one edge and ascending scarp at the opposite edge, widthwise. 
Tuff A volcanic rock (ignimbrite) deposited by a dense, fiery cloud eruption of rapidly moving suspension of superhot ash, and small particles. Usually very dense (particles welded together by residual heat after coming to rest).

Weathering rind Crust of oxidized iron mineral enveloping a cobble or boulder; formed by prolonged weathering. 
For more information concerning this publication, contact Center Director, USGS Geosciences and Environmental Change Science Center

Box 25046, Mail Stop 980

Denver, CO 80225

(303) 236-5344

Or visit the Geosciences and Environmental Change Science Center Web site at https://gec.cr.usgs.gov/ 

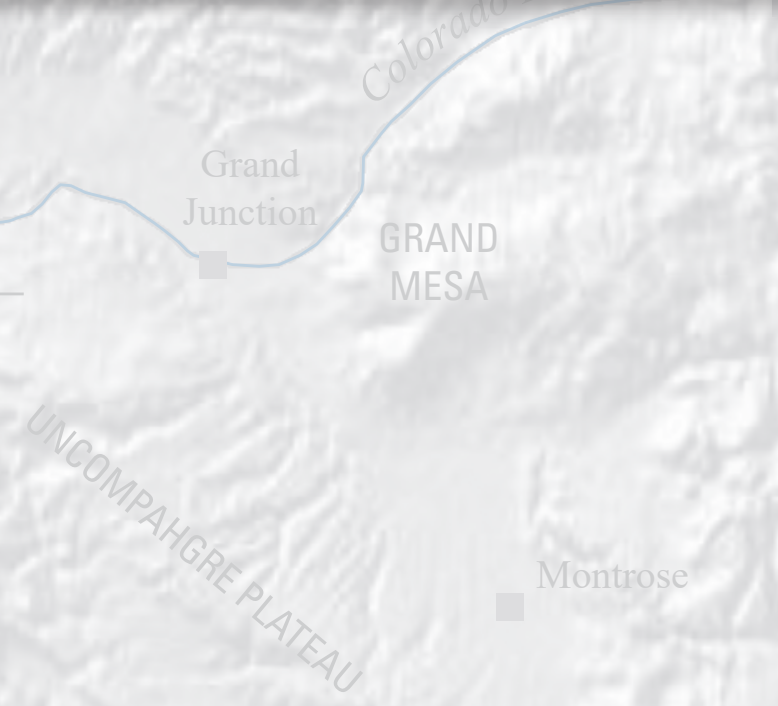

Montrose

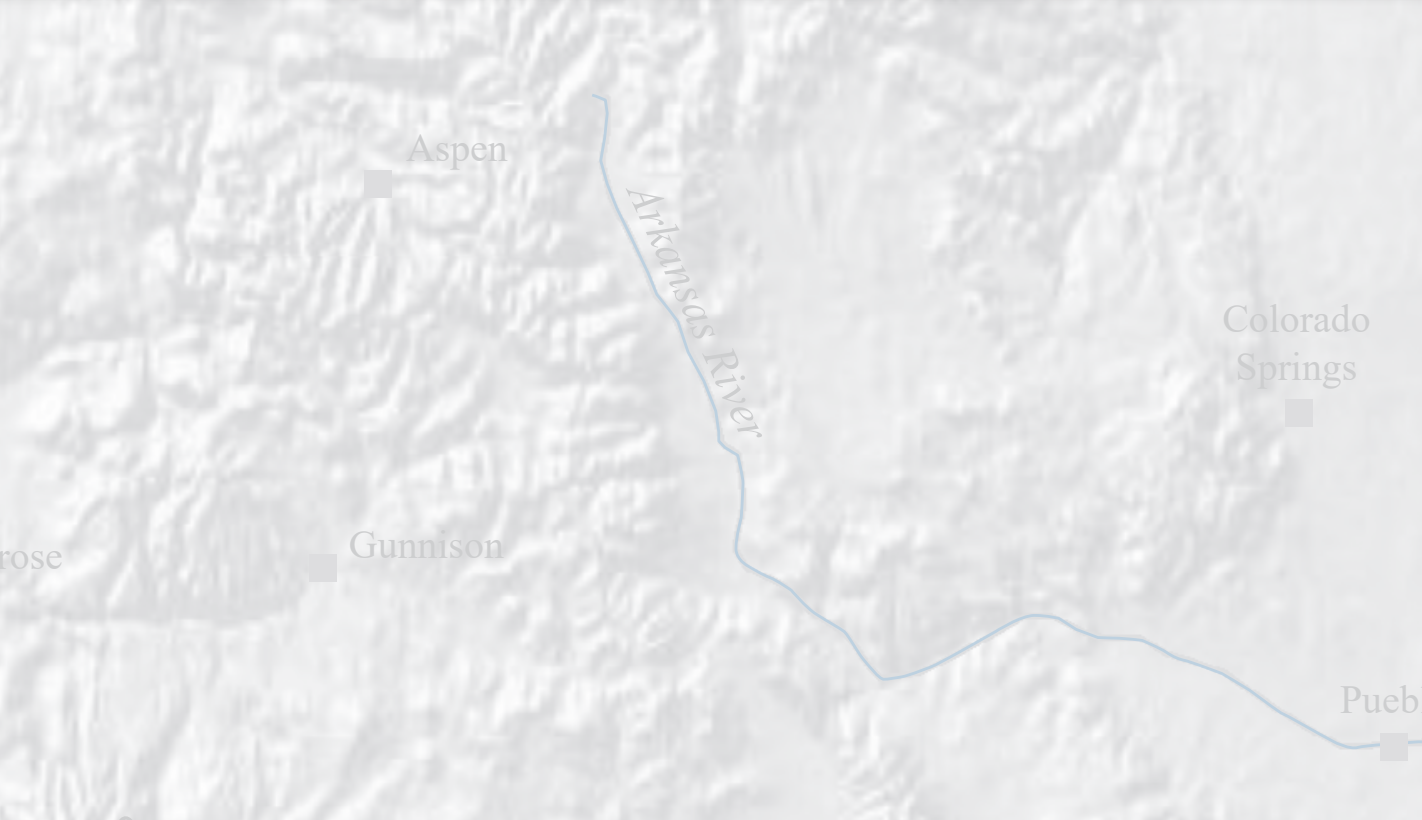

SAN JUAN

DOME

N BASIN RIM

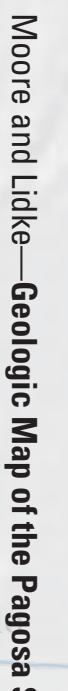

胥

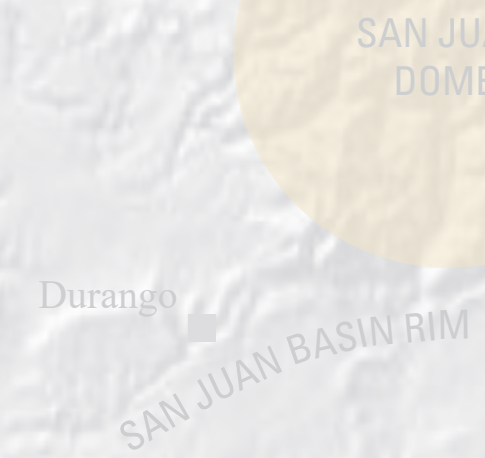

Farmington

sp 